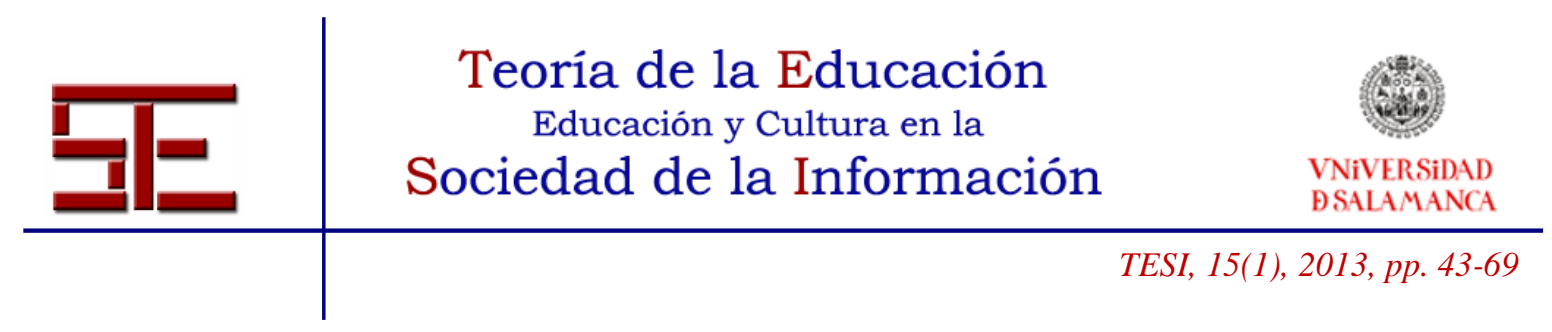

\title{
MEDIA LITERACY IN PRIMARY SCHOOL: NEW CHALLENGES IN THE DIGITAL AGE
}

\begin{abstract}
There are heated debates occurring around the world about the big changes and huge advances which technology has performed in our society. Digital divide, digital skills, knowledge and network society, unequal resources... These are all concepts we all have in mind when we think about what is happening in our environment with developments in technology. Even more so when we consider thoroughly what is happening in the education of our offspring.

Although the new digital environment offers great opportunities and possibilities of constructing knowledge, our society urgently needs different strategies in the educational system to ensure a comprehensive training in the digital age.

This essay will deal with the aspects of this new emerging society emphasizing that finding, evaluating and using information will be crucial for our children's future. The key aspect of this paper is how to empower children in their daily Internet browsing by introducing media literacy at primary school.

To this end this paper will present the results of a media literacy project named "Conectados" which introduces media literacy in the classroom using one specific tool: the iPad. With this new device the project tries to enhance the instruction of children between 7-8 years of age, who are in fact daily users of the Internet.
\end{abstract}

Key words: media literacy; knowledge society; primary school; technology in classroom; new skills; digital competences; Internet.

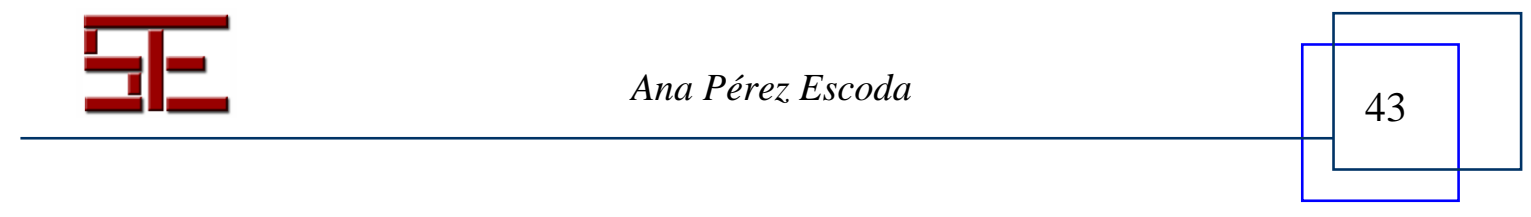




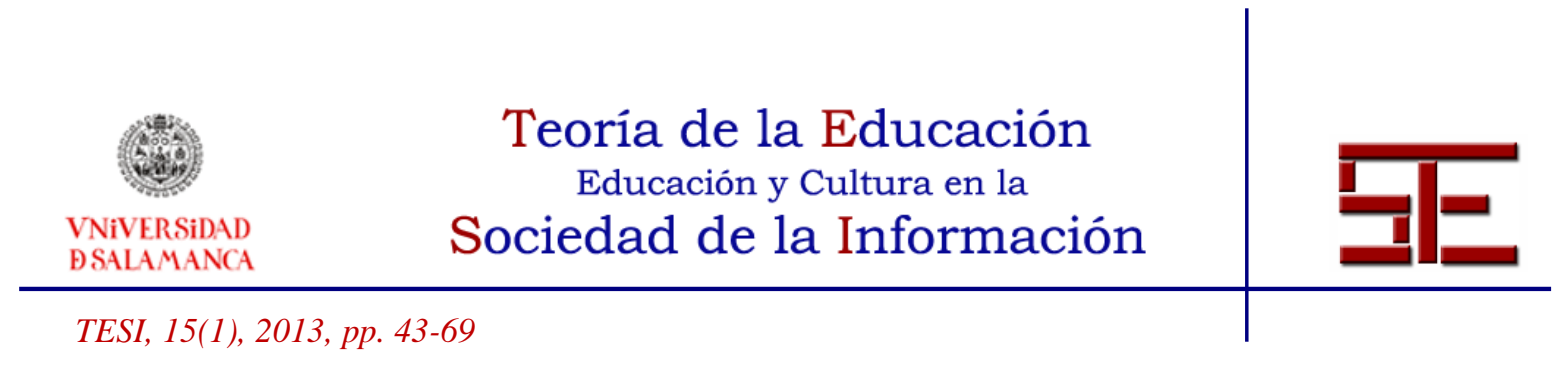

\section{ALFABETIZACIÓN DIGITAL EN EDUCACIÓN PRIMARIA: NUEVOS RETOS EN LA ERA DIGITAL}

Resumen: Actualmente se producen en el mundo acalorados debates acerca de los grandes cambios e inmensos avances que la tecnología ha hecho posible en nuestras sociedades. Brecha digital, competencias digitales, sociedad de la información y del conocimiento, desigualdad de recursos... todos éstos son conceptos que inevitablemente surgen al reflexionar sobre lo que está acaeciendo en nuestro entorno con el desarrollo tecnológico. Más aún si analizamos en profundidad cómo están repercutiendo estos cambios en la educación de nuestra descendencia.

A pesar de que este nuevo entorno digital ofrece grandes oportunidades y nuevas posibilidades de construir conocimiento, nuestra sociedad necesita urgentemente estrategias diferentes dentro de su sistema educativo que aseguren una formación adecuada en la era digital.

El presente trabajo pone especial énfasis en la importancia que tiene para los niños en esta sociedad emergente aprender a encontrar, evaluar y saber usar la información existente en la Red a través de una alfabetización digital desde la educación primaria.

Para ayudar en este propósito se presentan, además, los resultados de un proyecto de alfabetización digital en el aula "Conectados" utilizando una herramienta específica: el iPad. Con este dispositivo el proyecto pretende mejorar las competencias digitales de los niños a partir de 7-8 años de edad, que son, ya, usuarios de Internet.

Palabras clave: alfabetización digital; sociedad del conocimiento; educación primaria; tecnología en el aula; nuevas destrezas; competencias digitales; Internet.

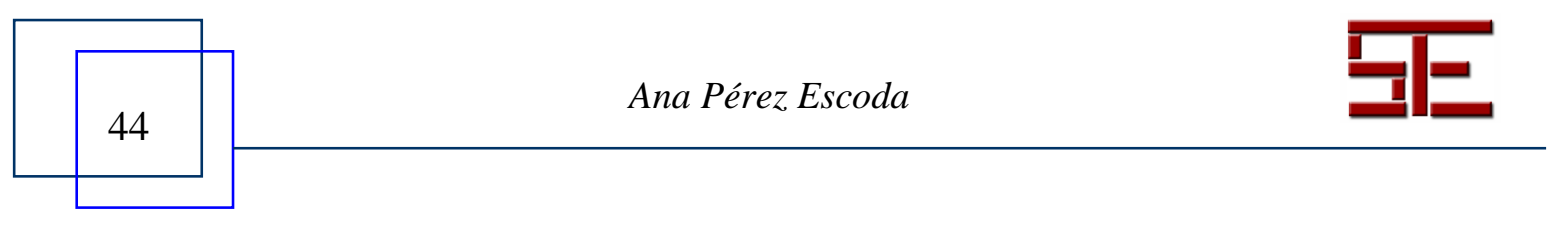




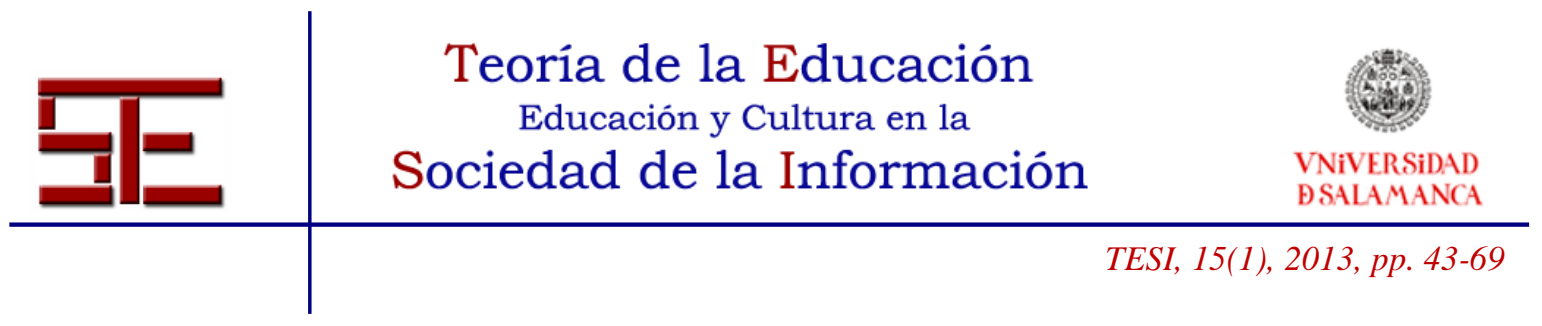

\title{
MEDIA LITERACY IN PRIMARY SCHOOL: NEW CHALLENGES IN THE DIGITAL AGE
}

Fecha de recepción: 21/010/2013; fecha de aceptación: 16/12/2013; fecha de publicación: 28/02/2014

Ana Pérez Escoda

apepanda@gmail.com

Universidad de Salamanca

\section{1.- INTRODUCTION}

The wider economic and social context called the Network Society (Castells, 2005; Cohen, 2009; UNESCO, 2005) is the framework for our essay. In its broadest sense, the term defines a historical moment in our civilization at the threshold of the $21^{\text {st }}$ century where the main characteristic is the amount of information generated every day on the Internet.

This moment has already been identified by many authors have such as Dominique Wolton (2000) who explains perfectly that the qualitative change taking place in current societies is the amount of accessible information and knowledge through ICT (Information and communication technologies) or Jan Van Dijk and Hacker (2003) who consider information as a primary good in our society:

\begin{abstract}
In an information society, information is known as a socalled primary good. Everybody needs it to function in society. However, people also need cultural capital (Mansell and Wehn, 1998) to use information in appropriate ways - that is, the skills to select and process information and be able to use it in ones social position and network. These kind of "capital" are distributed very unequally in society. Moreover, information is a positional good. This mean it becomes increasingly important to get the information first in economic, social, and cultural competition. This is why it is so important to look at the relative differences in all inequalities observed (Van Dijk, and Hacker, 2003)
\end{abstract}

The key to interpreting this new state of affairs lies in the two crucial processes that emerged during final years of the $20^{\text {th }}$ century and the early years of the $21^{\text {st }}$ century: "digitalization", described by Nicholas Negroponte (1995) and "convergence culture" a new perspective of facts exposed by Henry Jenkins (2008). Both concepts are essential for understanding the current situation.

Digitalization led to a radical change in the way information is generated and managed. By replacing the main support of knowledge and awareness, it has resulted in changes in the way people talk, think and communicate with each other. Henry Jenkins explains "convergence culture" in relation to participatory culture as the flow of content across multiples media platforms that increase an emergent collective intelligence.

Additionally, our current society is suffering yet another change described by Bauman (2007) as "liquid modernity", a concept which challenges the meaning of modernization. As Bauman has written, our life has abandoned the solidity of the past

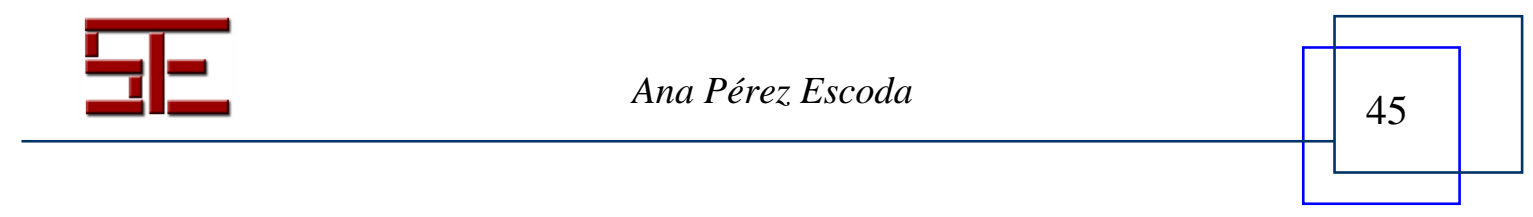




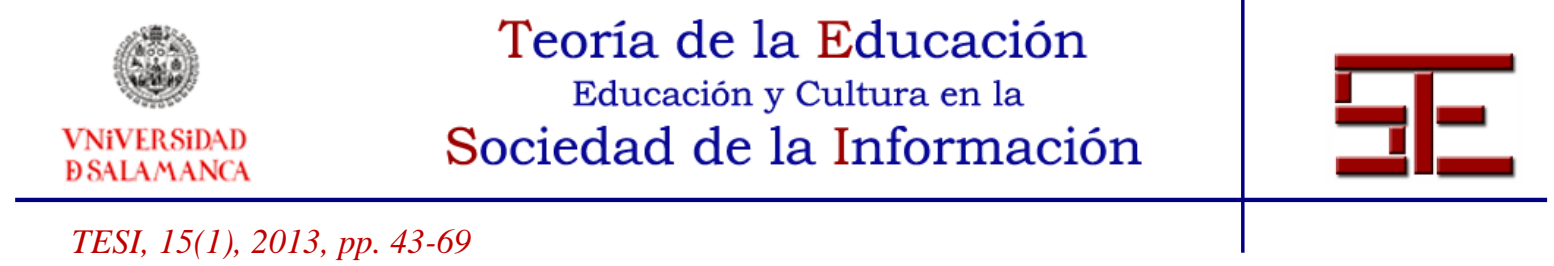

and become liquid. This concept must remind us that our children and the youth of our society must face the future with a different logic than ours.

Subsequently the field of education has a lot of work to do, not only teaching new codes to explain the world or showing the reality offered in different screens, but also in educating students in new skills, in a new media literacy. The issue, then, is not how media are instructing us in new media literacy, but how to teach our children in a critical learning to control this new literacy, to control the necessary skills in the digital age (Cope and Kalantzis, 2009; Lankshear, 2008; New London Group, 1995).

While everybody is exposed to the speed of technological advances, children and the youth of our society are more involved in these changes because they develop new and uncontrolled skills to manage information and use new devices in their daily lives (Aguaded-Gómez, 2011). According to Prensky they are the "digital natives" (Prensky, 2011), but the question is: Is this generation of "digital natives" prepared to face the real challenges of the future? Are they being prepared at schools with the proper skills to face the digital age? The spontaneous use of information and communication technologies does not automatically imply the acquisition of these skills. In line with this argument Deursen and Van Dijk (2010) have studied and refined the concept of digital/Internet skills to propose six different skills needed in the digital age to manage digital mediums.

Table 1. Six types of digital skills applied to Internet skills by Jan Van Dijk $(2012,67)$

\begin{tabular}{|c|c|c|}
\hline \multirow{2}{*}{ 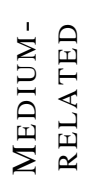 } & OPERATIONAL SKILLS & $\begin{array}{l}\text { Actions required to operate a digital medium } \\
\text { ("button knowledge") }\end{array}$ \\
\hline & FORMAL SKILLS & $\begin{array}{l}\text { Handing the formal structures of the medium; } \\
\text { browsing and navigating }\end{array}$ \\
\hline \multirow{4}{*}{ 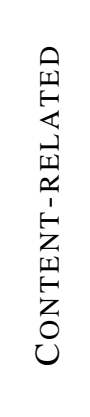 } & INFORMATION SKILLS & $\begin{array}{l}\text { Searching, selecting and evaluating information in } \\
\text { the digital medium }\end{array}$ \\
\hline & COMMUNICATION SKILLS & $\begin{array}{l}\text { Mailing, contacting, creating online identities, } \\
\text { drawing attention and giving opinions }\end{array}$ \\
\hline & CONTENT-CREATION SKILLS & $\begin{array}{l}\text { Make contributions to the Internet with a particular } \\
\text { plan of design }\end{array}$ \\
\hline & STRATEGIC SKILLS & $\begin{array}{l}\text { Using the digital medium as a means to achieve } \\
\text { particular professional and personal goals }\end{array}$ \\
\hline
\end{tabular}

Taking this digital environment and these theoretical arguments into account, this paper strives to merge theoretical and practical field and present a pilot-project that introduces media literacy in the classroom. The main goal will be to contribute to the greatest possible extent in the development of new material related to the use of the Internet and

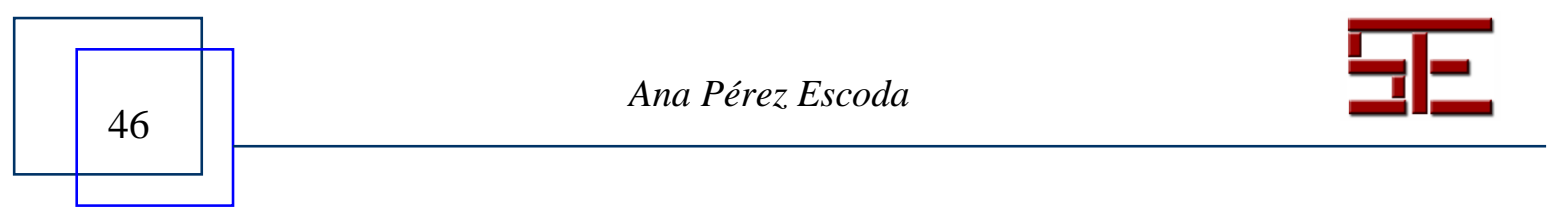




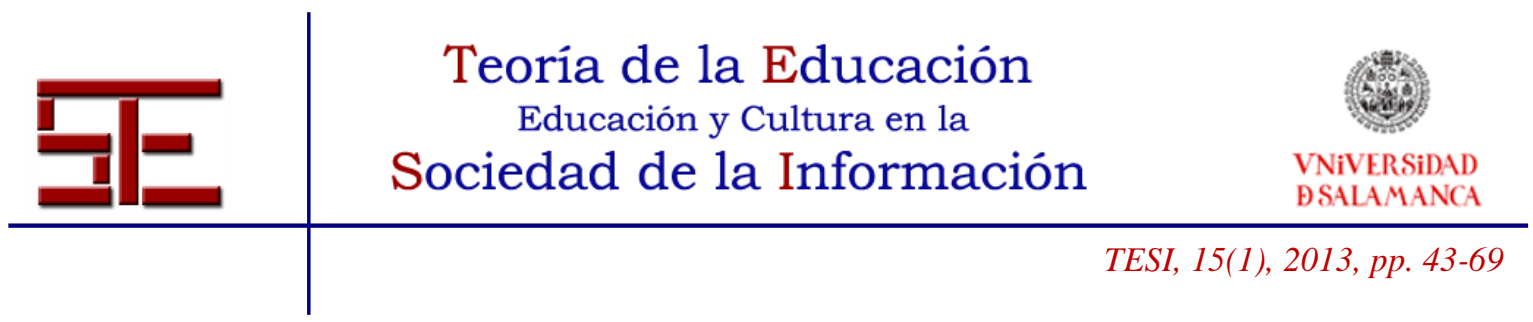

the skills it requires, and in the real educational use of the iPad: a new device in the classroom which digital natives are perfectly capable of managing.

To put this pilot-project into practice we had to deal with a new challenge: children between 7 and 8 years of age (second level in Primary Education) using iPads in the classroom and learning new materials and new tools. Would they be keen on working these new skills? Would we be able to make them learn new concepts related to the Internet? Was this the appropriate age to start with this kind of teaching?

This paper aspires to answer these and other questions that could emerge regarding the introduction of media literacy at Primary Schools. To this end, the following paragraphs outline the main arguments as to why it makes sense to talk about media literacy and why it is so convenient to introduce it in the Primary school classroom. Finally, we will present our case study with the various steps, aims, achievements and conclusions, hoping that this small contribution will contribute toward the great task of teaching the proper competences to the young digital natives of our network society.

\section{2.- WHY WE NEED TO TALK ABOUT MEDIA LITERACY ${ }^{1}$ IN PRIMARY SCHOOL}

Keeping in mind everything said thus far, this paper find its main support in the UNESCOs Media and Information Literacy Curriculum for Teachers:

This Media and Information Literacy Curriculum for Teachers is an important resource for Member States in their continuing work towards achieving the objectives of the Grünwald Declaration (1982), the Alexandria Declaration (2005) and the UNESCO Paris Agenda (2007) all related to MIL. It is pioneering for two reasons. First, it is forward looking, drawing on present trends toward the convergence of radio, television, Internet, newspapers, books, digital archives and libraries into one platform - thereby, for the first time, presenting MIL in a holistic manner. Second, it is specifically designed with teachers in mind and for integration into the formal teacher education system, thus launching a catalytic process which should reach and build capacities of millions of young people (UNESCO, 2011, 11).

All the countries involved in this project are concerned about demanding the educational system provide new competences, new skills required in our complex and changing world: media literacy (Andretta, 2007; Bruce, 1997; Catts and Lau, 2009; Diehm and Lupton, 2012; Weiner, 2010). According to Bautista García-Vera (2007) and Churchill, Churchill, Lim Cher Ping and Oakley (2008) media literacy must be multimodal; that is, digital technologies should enable a traditional text to become a multimodal text by adding image, audio, animated sequences, transition and video into multimodal texts (Kress, 2006).

Traditional literacy at schools presents a lack of contents, a lack of skills concerned with managing, processing and assuming the amount of information generated every day in

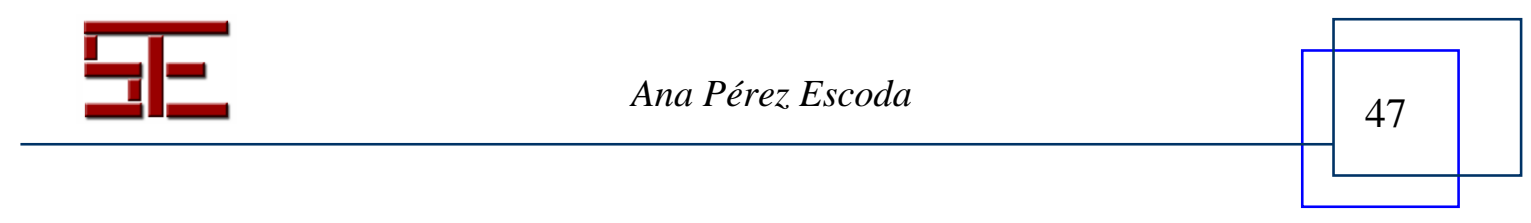




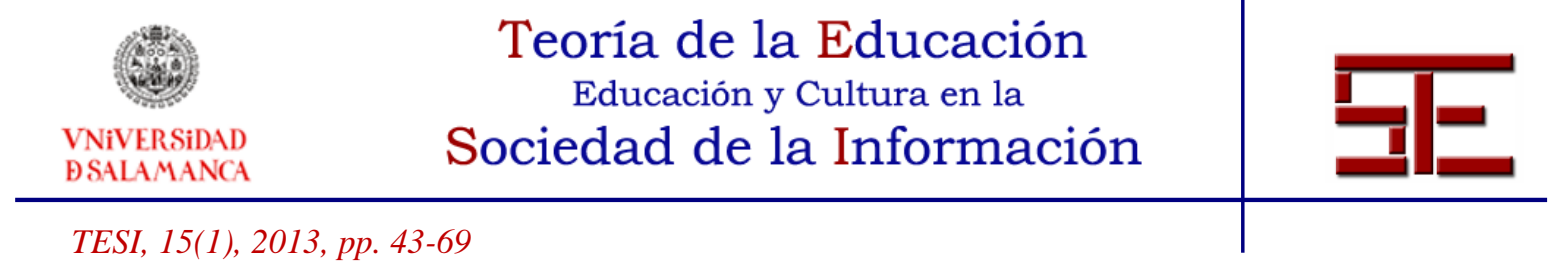

the Internet. Furthermore, we are experiencing an explosion of new devices that provides children and our youth with a continuous connectivity and interactivity.

Focusing on this idea the study by Bringué and Sábada in Spain explores how technologies have spread into the household "In the case of the Spanish children it could be said that the penetration of the computer is almost universal: $95 \%$ of the youngest children (6-9 years old) and 97\% of the oldest (10-18 years old) claim to have a computer at home" (Sábada and Bringué, 2010, 95). The study shows the high level of mobiles penetration and how its use begins at earlier ages; moreover the authors provide a chart illustrating how children above 10 years old prefer surfing the Internet to watching TV (Sábada and Bringué, 2010, 97). Given that new generations are using Internet in computers or in mobile devices our proposal will try to introduce formal instruction in the classroom regarding the Internet and its use by working with both digital skills and traditional skills. These required abilities and skills are not new per se (Churches, 2009), instead it is the technological environment surrounding us which keeps changing continuously.

The proposal of working media literacy in primary school is to develop new resources in order to help teachers in classroom enhance and approach a real new literacy. Talking about new literacy is not only talking about media literacy; it is absolutely necessary to understand a wider concept that integrates different literacies to configure a proper new literacy. This could be the key point for success in the future when citizens with digital skills and digital literacy will be able to solve problems that those lacking the proper education are unable to do on their own. After all the welfare and development of a nation depends on the abilities of its citizens. Related to this point Daniel Churchill (2009) explains that "today's new literacy", Figure 1, is composed of different literacies, all of which need to be taught for the construction of meaning and knowledge.

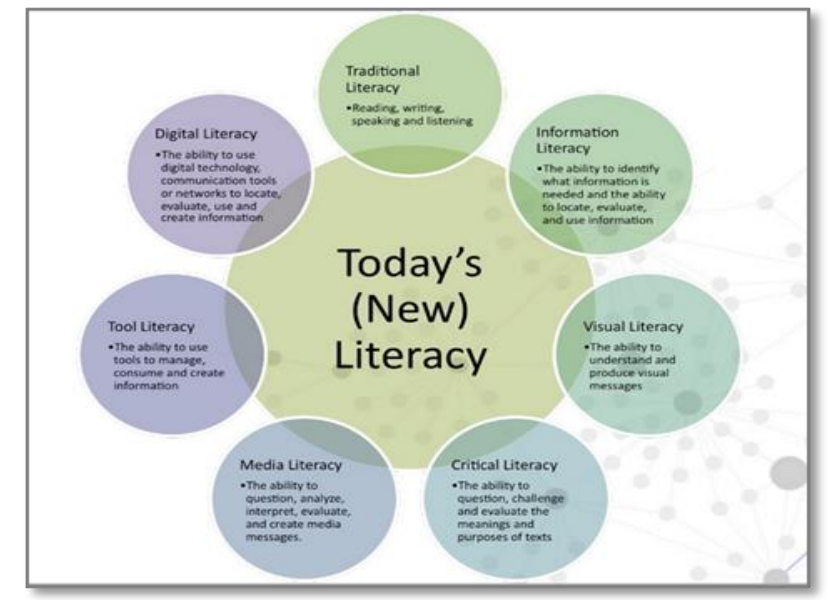

Figure 1. Daniel Churchill. Today’s New Literacy

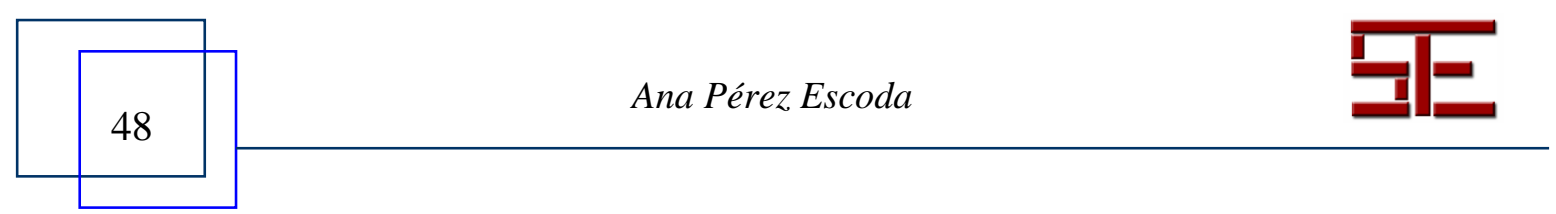




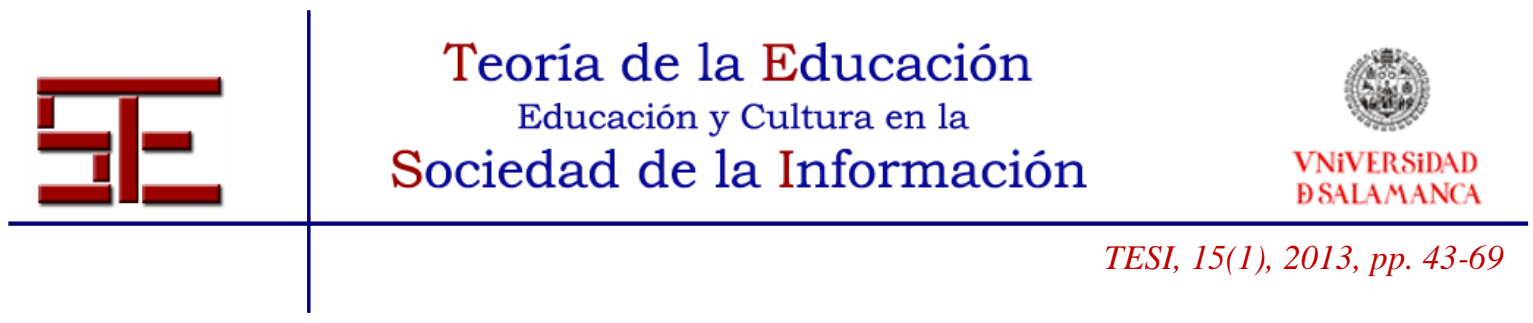

As shown in Figure 1, literacy has unfolded and developed into a wide range of literacies to train students in the abilities needed in a global society: multiliteracies ${ }^{2}$. This means that traditional literacy, information literacy, tool literacy, media literacy, digital literacy and critical literacy, are all equally important (Burn and Durran, 2007).

Obviously, the curricula in schools today do not cover all the literacies needed for our students. Although it may seem new, it should be noted that the concept of multiliteracy is in fact at all; the concept was coined in 1996 by a research group in the field of educational called New Group of London (1995). They argued that the multiplicity of communication channels and increasing cultural diversity call for a much broader view of literacy. This idea might be reconceptualised in the digital age to maximize educational development for all in an era of globalization and continuous technological change.

\section{3.- CONSTRUCTING KNEW KNOWLEDGE: MAIN COMPETENCES IN MEDIA LITERACY}

In spite of everything argued to this point, we understand that reaching an agreement about the real and deep sense of media literacy (digital competence) is no easy task. In fact in our attempt to develop it as a new material we have found different perspectives and views. International surveys and academic literature mostly warn that many people lack digital capabilities: this is related to the digital divide.

Inequality related to technologies creates very big differences between people around the world in broadly speaking, two different ways: people who have access to resources and technologies and people who do not; and people who know how to use the technologies and take advantage of its use and people who do not (Van Dijk and Hacker, 2003).

However, the intention of this essay is not to pursue this categorization; instead, the real intent is to fill the digital gap between those who were born before the explosion of ICT (information and communication technologies), and those who were born and are growing up with ICT in their hands. The true goal is to avoid a bigger gap that would render future citizens incapable of managing the unlimited flow of information and hence be controlled by the industry of the Internet.

It is important to realize that we are a very informed society, but without competences that allows us to construct knowledge and measure the reliability of this flow of information. This situation could cause future citizens to become mere puppets in the "potlatch" of the Internet (Ortega and Rodríguez, 2011).

Given this situation it is crucial in our argumentation to clarify which areas of the digital competence or media literacy could be developed and taught in classroom. In 2006 the European Recommendation on Key Competences ${ }^{3}$, digital competence was

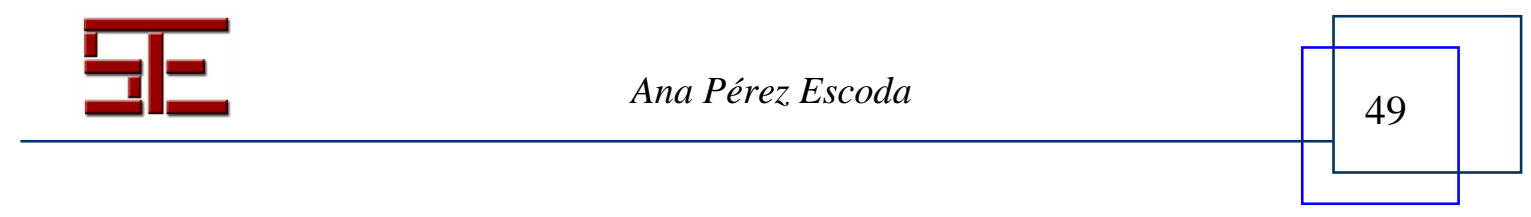




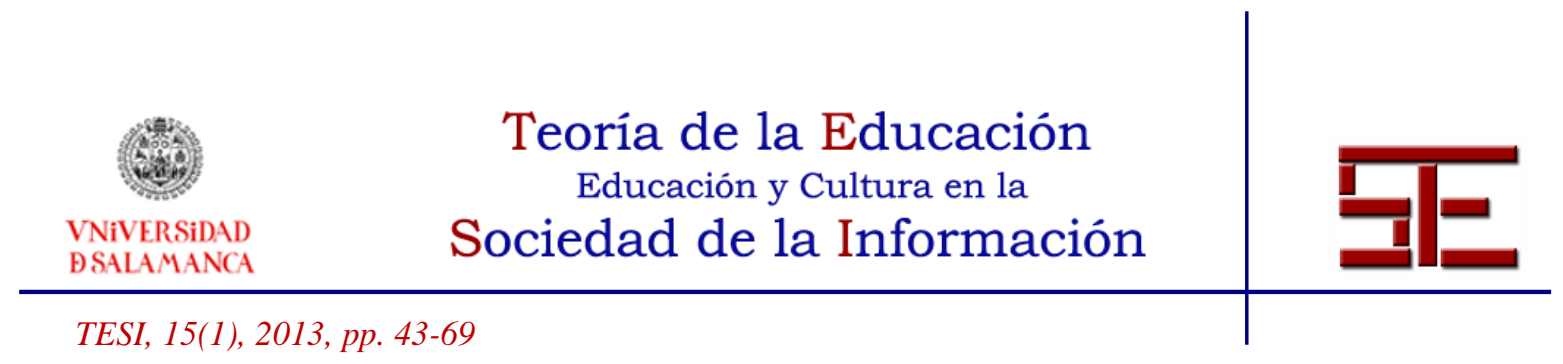

acknowledged as one of the 8 key competences for lifelong learning. Based on this document in 2013 we find the DIGCOMP: A Framework for Developing and Understanding Digital Competence in Europe in which digital competence is defined as "...the confident, critical and creative use of ICT to achieve goals related to work, employability, learning, leisure, inclusion and/or participation in society" (Ferrari, 2013, 2).

This work is the perfect framework for our proposal. The report suggests a descriptive mapping of the competences related to digital competence as seen in table 2 (Ferrari, $2013,12)$. It is worth noting these are the theoretical issues needed in the development of a new subject called media literacy (which is proposed in our case study).

Table 2. Overview of competence areas and competences

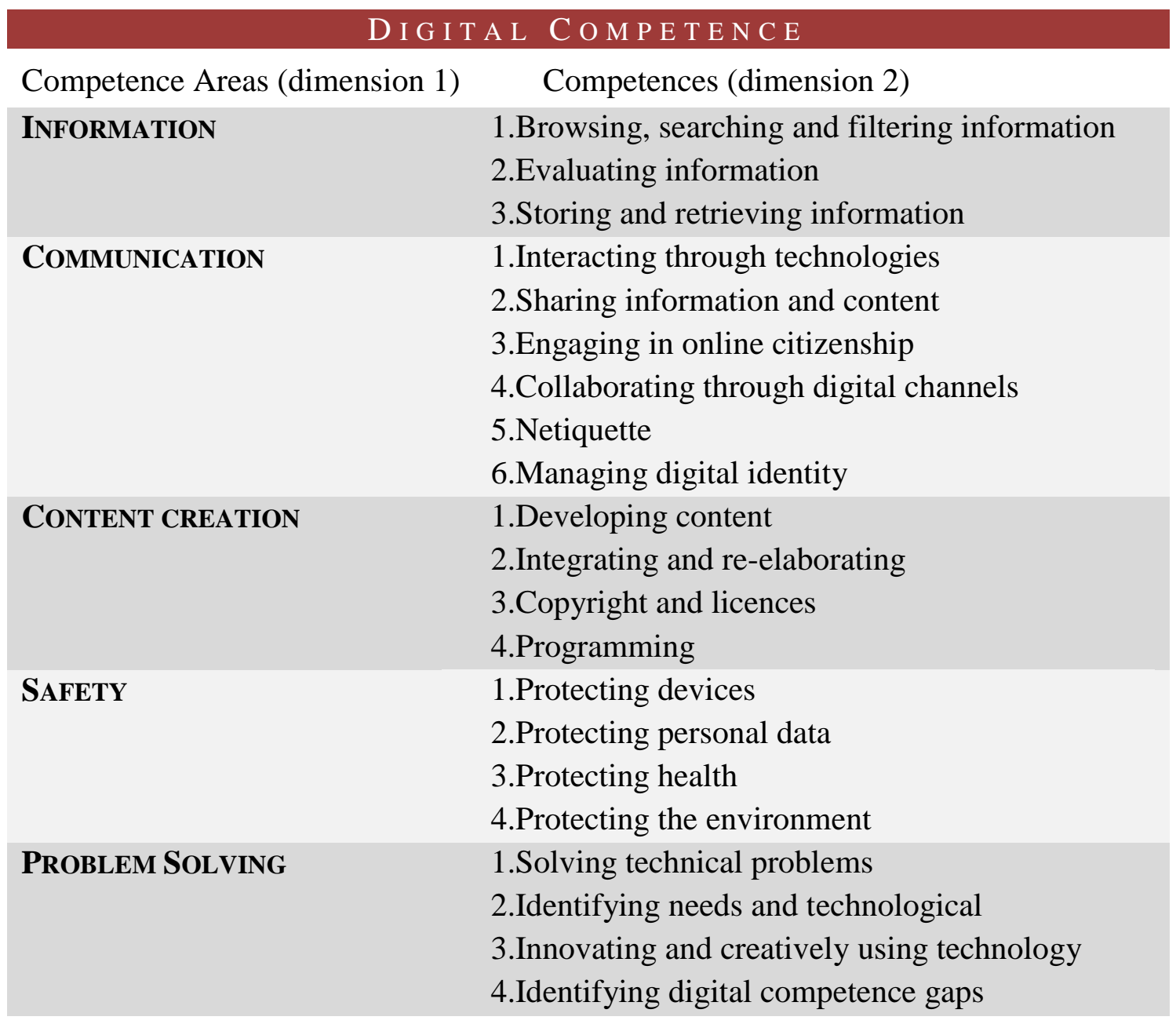

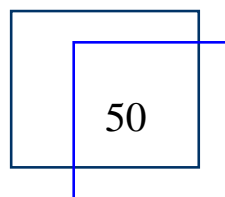

Ana Pérez Escoda 


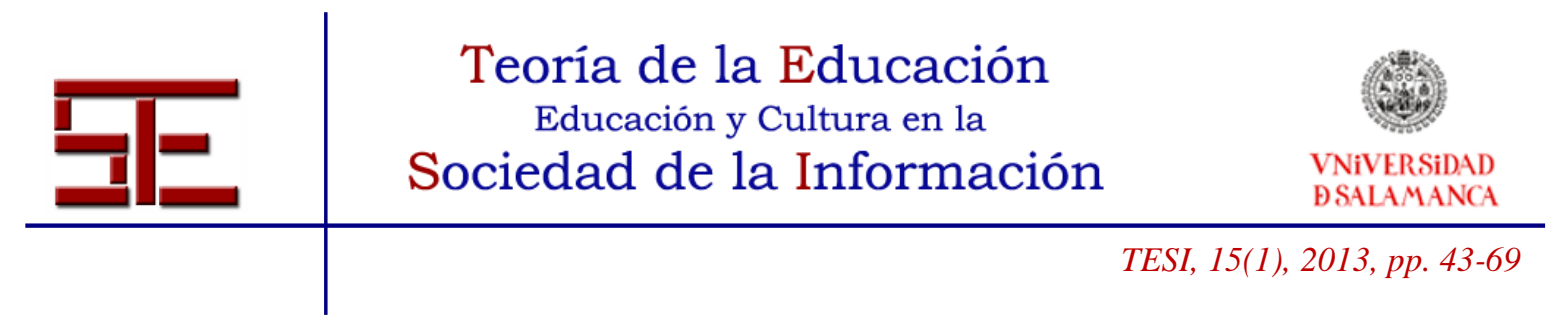

\section{4.- A CASE STUDY OF MEDIA LITERACY AT CLASSROOM: THE PROJECT}

In a society where so much importance is placed on information, citizens must know how to manage this information, how to distinguish the sources they use, how to store the information, and how to recover it. If they are going to be citizens in a digital world, they must know how to create a digital identity, how to behave in the Internet and determine whom they can trust in the net.

These ideas are at the core of this project and its belief that teachers from the classroom need help, they need resources to teach children the codes of this new literacy. Contributing to the field of education is the responsibility of all its members if a real change in the educational system is to be achieved.

This article presents a case study, prepared and developed during one year, which introduces media literacy to the classroom. The project presented was conceived and designed as a pilot project to teach students new concepts related to the Internet, and to teach the skills required to manage the internet with a new device: the iPad (Area y Guarro, 2012; Collins and Halverson, 2009; Jewitt, 2002). The tool proposed as a proper tool for the digital age is the iPad because it offers several conveniences for a project such as ours. Firstly, every student can manage it him or herself. Secondly, it allows working with many apps and can be connected to the Internet thus enabling students to work together. Finally, it is an engaging tool for students.

Based on the assumptions previously explained, the aims of this project are the following: a) to test reality with an initial case study about the digital skills of digital natives; b) to prove the need to enhance media literacy through the development of new materials and resources, striving to merge the work between schools, researchers and parents; c) to leverage insights the students have about the Internet and its use in order to improve digital skills among children in the digital age and d) to contribute as much as possible toward the huge task of making change possible in the educational system approach to learning of new skills in the digital age, which is very much needed for our students.

Before describing all the steps and the research, it is important to extend the most sincere gratitude to CGB Informática for lending us 20 iPads to use in the classroom, and to the Maristas Champagnat school in Salamanca, which opened its doors to the project, especially to Mario Miguel Hernández the tutor in the classroom where we worked.

\subsection{First step: testing the motivation and previous knowledge}

This first step focuses on obtaining information about the students to help us design the new resources. The information is gathered from two different sources: a motivation test and an assessment to obtain information regarding previous knowledge, which will help us to design new materials.

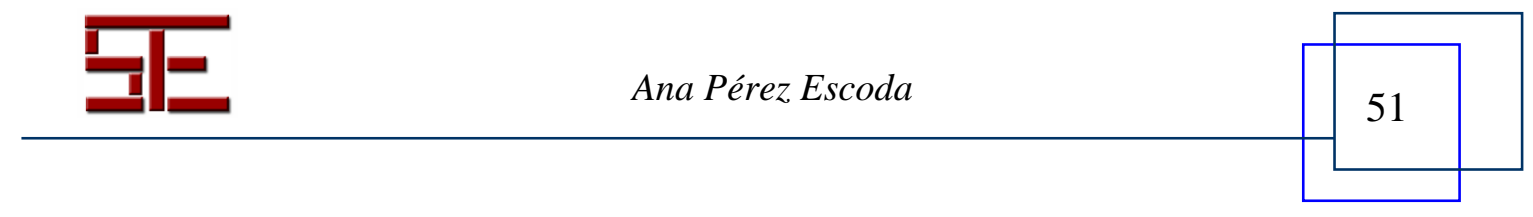




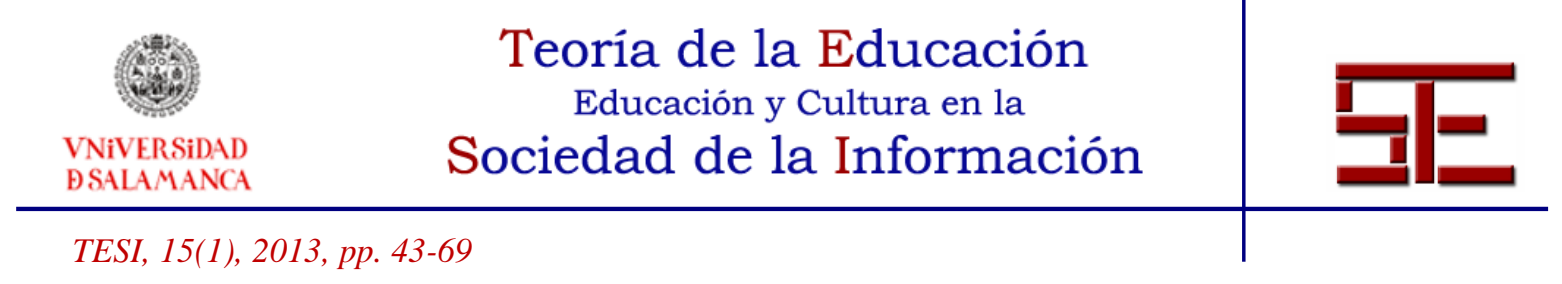

Main objectives: a) open a website so that the project and its progress are made public; b) know and check the motivation level of students at school in order to know if they will welcome the new content and new challenges and c) assess and measure the previous knowledge children have about the Internet with regards to both concept and usage.

Steps: a) Check and review current bibliography; b) design and develop a website for the project in order to gather information about the activities the children do in the classroom with the iPad to learn about the Internet and how they must use it http://bit.ly/13pXYMM; c) apply a motivation test to check how the students feel about being in a classroom; and d) conduct interviews to determine previous knowledge.

\subsubsection{Methodology and Development}

The methodology in this step is presented in two different parts: one related to the motivation test, and the other to the interviews determining previous knowledge the students had about the Internet.

Motivation test:

Our case study is qualitative and descriptive. It is a quasi-experimental design because the sample is not created through a random assignment; rather it is formed by 26 students between 7 and 8 years of age, from the classroom where we have applied the new resources.

We begin this first part with a motivation test in order to be aware of how children feel about being in a classroom. This will help us understand how they will approach the new contents.

The instrument selected to assess the motivation of students from 8 to 12 years old is a questionnaire. It is composed of 10 dichotomous questions, with true or false answers, designed by Professor Ávila de Encío.

The procedure in this case is to administer the questionnaire in the classroom in order to mitigate obsequiousness bias and social desirability. An adult who is not the students' regular tutor administers the survey. However, this individual is somebody whom the students trust and who assures them that their tutor will not read the answers and that the questionnaire is completely anonymous.

Interview:

As previously mentioned, our case study is qualitative and descriptive and we use the interviews to focus specifically on the previous knowledge the students have about the Internet. The objective in such a study is to capture the feelings and opinions of the students without manipulating the variables.

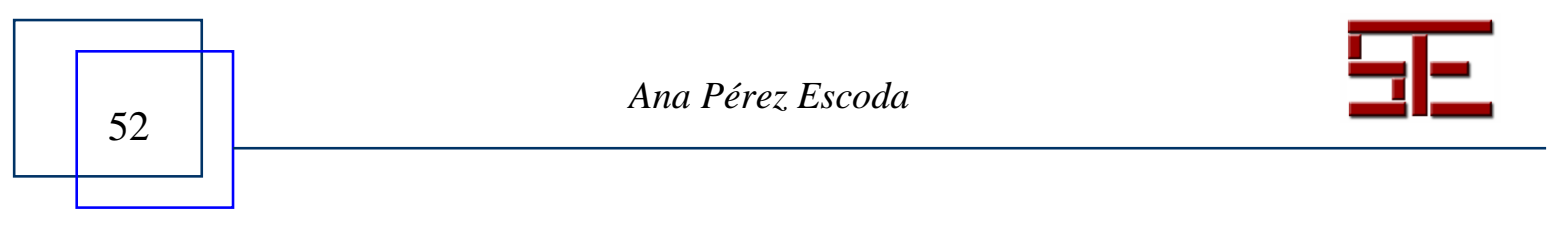




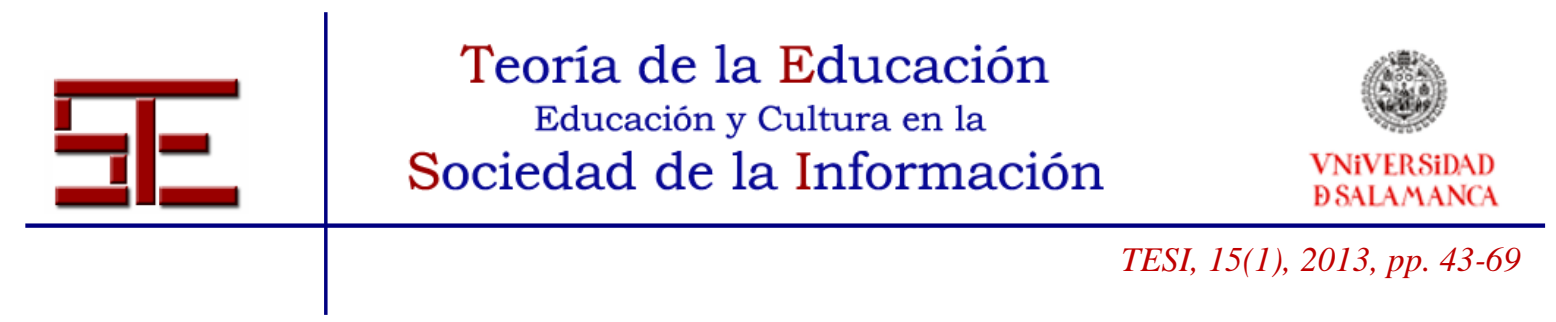

The sample in this case study is composed of 26 students between the ages of 7 and 8 . The interview designed has 9 variables (as shown in the graph below) that will give us the information needed for the design of the project.

The same person who prepared the motivation test carried out the interview. The method used for the data gathering is the following:

he interviewer arranges a table and two chairs in the same classroom where the students are. On the table there is a laptop.

2

he interviewer invites the child to talk with her for a while. Every child answers the same questions written on slides and shown on the laptop screen. See Figure 2.

3

he interviewer uses the slides as a means of conducting the interview. This way the students do not realise they are going to be recorded with the webcam, and the response will be more sincere.

4.

he students talk to the interviewer in a familiar environment for them: the classroom, which makes the interview easier and more fluid.
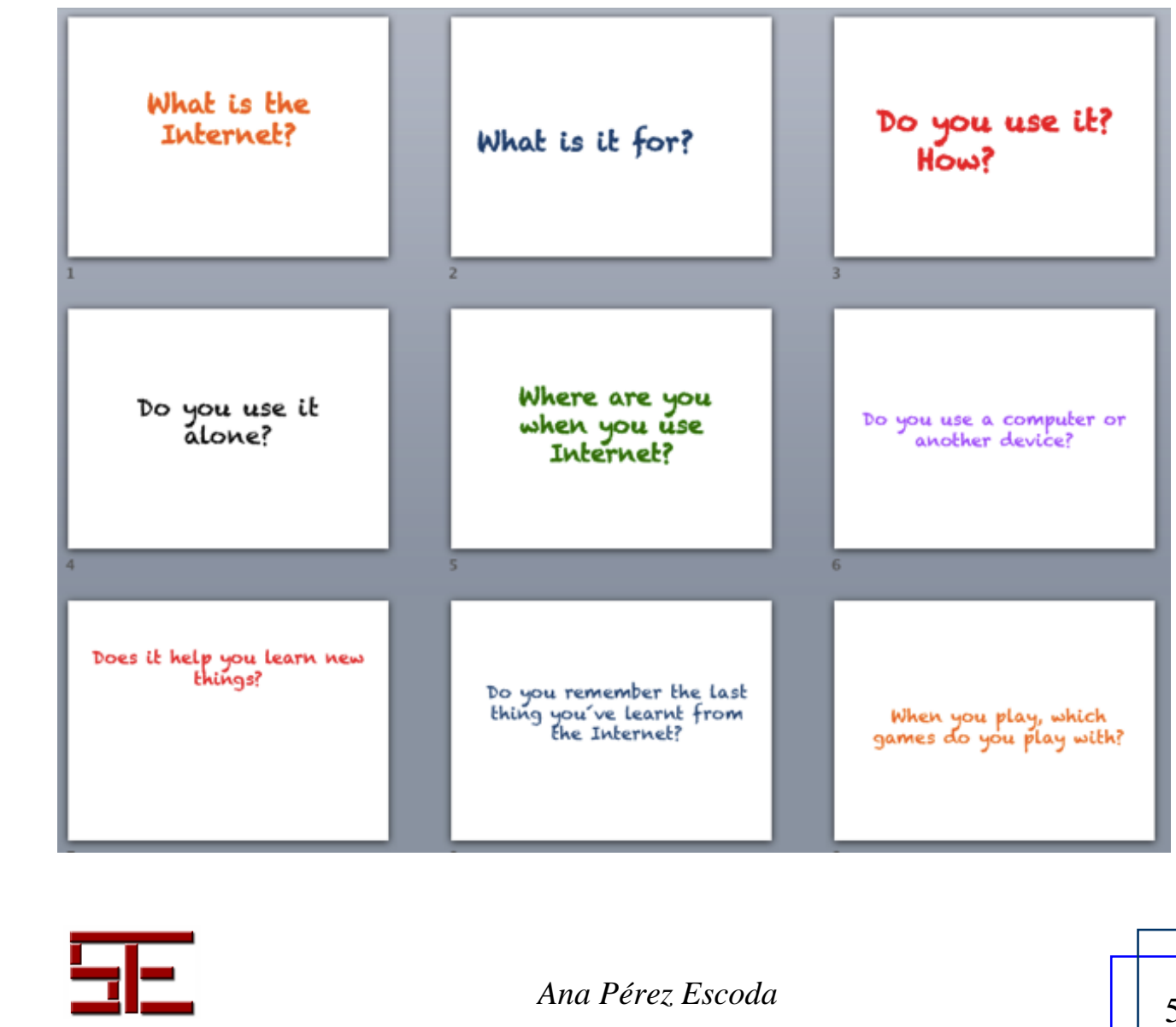

Ana Pérez Escoda 


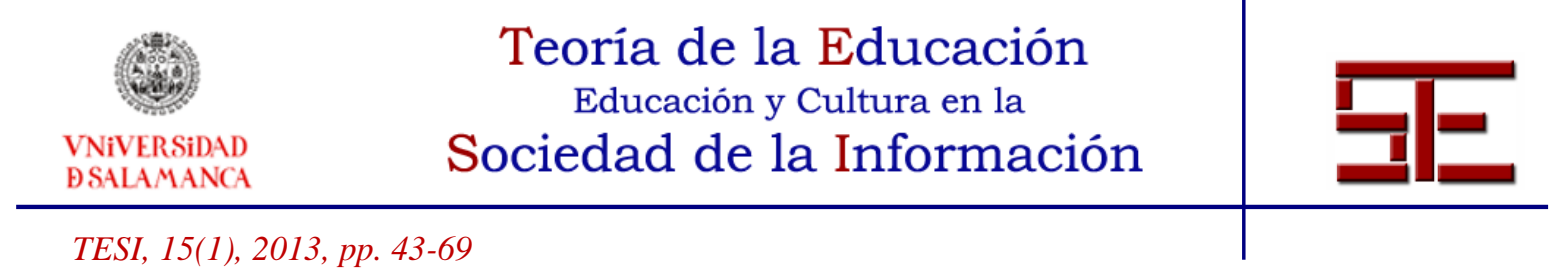

Figure 2. Slides used in the interviews.

\subsection{Second Step: Constructing new knowledge}

Main objectives: a) to develop and put into practise new resources and new material created taking into account the use and prior knowledge students had about the Internet, as well as their motivation level; b) to use a new device, the iPad to enhance the teaching in classroom and teach students an educational way of using ICT and c) to assess and measure the additional training given to children.

Steps: a) review of all data obtained in the previous step; b) the design and development of a project blog where every session has been explained, the units, the aims and the methodology: http://bit.ly/12TIEZT. This allows parents to follow the progress of the sessions; c) assessment to check the acquisition of knowledge with the new resources in classroom. The online tool used was a classroom blog (http://bit.ly/14Je7OH) where children loaded the exercises done on their iPads; d) survey to the student's parents to check if they agree with this new material being taught in classroom and whether they consider it as necessary.

\subsubsection{Methodology and development}

In this step of the project the main purpose was teach children new contents by introducing them in the media literacy. The methodology to achieve this aim was:

1.After explaining the theoretical contents to the children, i.e. new concepts and definitions, the aims and the necessary tools for the activity were revealed to the students (the activities were performed with different apps).

2.Students, alone or in pairs (because we had 20 iPads available and 26 students) worked on the activity in the classroom.

3. Once finished and signed with the name of every student, the exercises were sent to the classroom's blog through email.

4.The email address, which was given to the students, allows them to automatically download the exercises in the blog in order to share it.

5.When everybody finished and sent the exercises, the results were discussed in the classroom using the interactive whiteboard (http://miclasesegundoc.blogspot.com.es/).

\subsubsection{New contents for media literacy}

Assuming that this is new material which is not included in the teachers curriculum to be taught in the classrooms, we will follow the tips proposed by professor Alonso Tapia (2005) such as the correct methodology to establish an effective content, adapting it to the student's age (7 years) and their psychology.

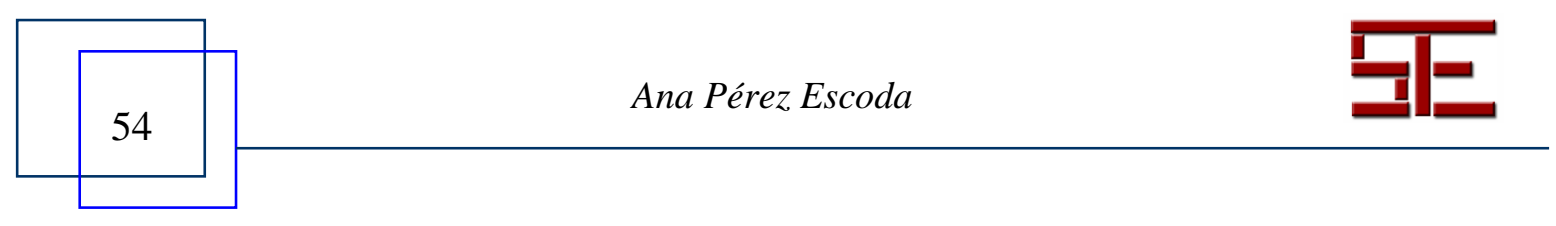




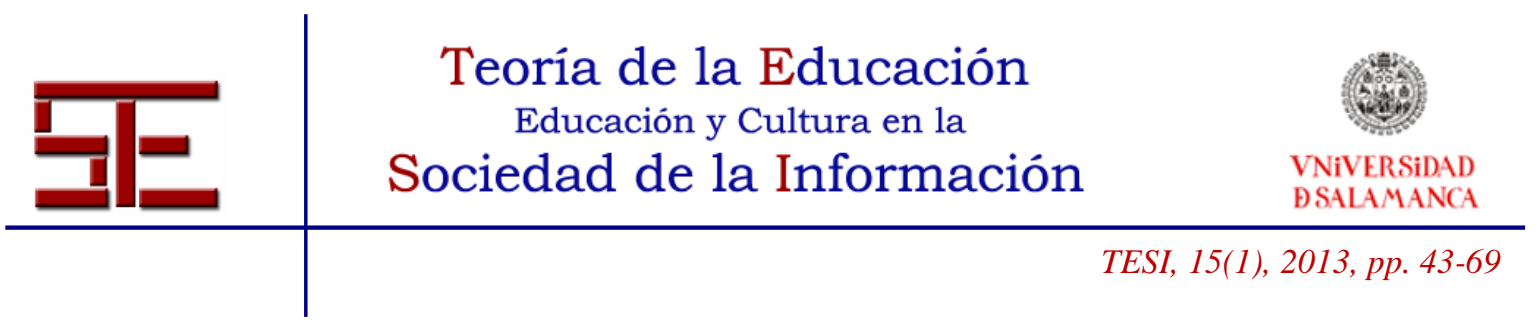

Taking into account the number of sessions that could take place planned the number of units and their extension.

Unit 1. Rules for using of the iPad: we introduce the new tool in the classroom: new tool, new rules. It is necessary for children to know from the beginning how to behave in order to reach the aims of the activities.

Unit 2. Beginning with the iPad: parts and main functions. Children learn how to manage and control the new device using the main functions and buttons. They must know how to use it in order to work properly with the next activities.

Unit 3. A new concept: what is an App? Strengthen the skills for using the new tool through the math competences. In this case using apps to do multiplication.

Unit 4. Communication: People communicate with each other. Learning what the Media are (TV, radio, newspaper...) in order to understand what the Internet is. This and other related concepts such as connexion, sharing information, blog, mail... One activity is created to check the understanding achieved and to achieve effective learning:

Activity: We introduce a new app: Skitch and the mail app. The goal of this activity is to practice with the iPad and think about the content learned. Students have to write three different ways of communicating; once finished they have to send it by mail to our classroom blog. We learn and share our work.

Unit 5. Communication and Internet. Surfing the Internet, downloading, sharing and communicating information. In this unit we strive to relate our communication skills with the possibilities provided by ICT. We learn the meaning of the concept "browser" using Safari.

Activity: In the next step, we practice with a real subject: Science. In this case we are going to use two new apps: Photos and Safari. The students must search for a photo of an animal, and then copy it in the Skitch. Once this is done they write the animal features (which they have learnt in the Science subject). Finally they share their work by sending it to the classroom blog.

Unit 6. Good behaviour: the aim of this unit is to remind and emphasize good behaviour while at the same time practicing with another new app and getting more confident using the new iPad tool. In this case we use a new app, Balloon.

Activity: Different kinds of circumstances between the children are written on little pieces of paper. The students are arranged in pairs, every pair must act out the situation they have on their little piece of paper. They will work in groups of four, each pair takes a photograph of the other two. Once they have the picture they will use the Balloon app to add dialogs in the balloons. Once the exercise has been completed they will send it by mail.

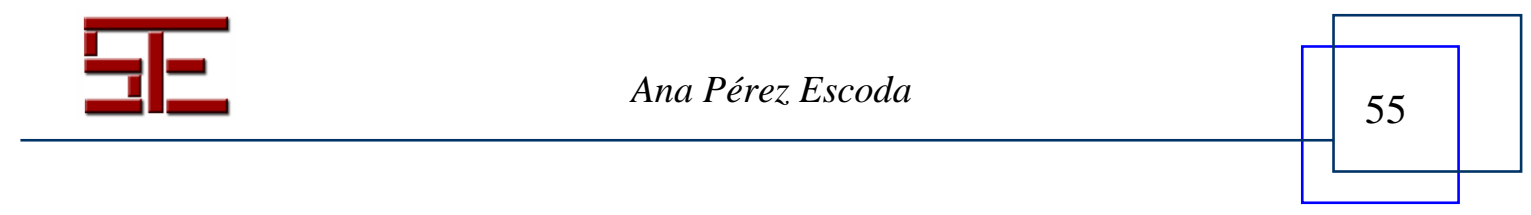




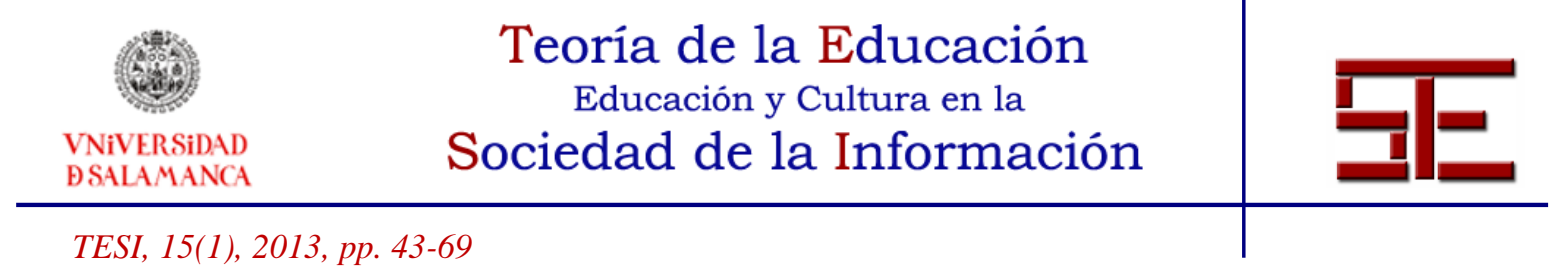

Unit 7. The Internet: what is it and what is it for? What is a browser? What is a search tool? Which are the best search tools for kids? Learning which are the best search tools for their age: bebeeee.com, aolkids, gogooglemykids, kidrex, quinturakids... related concepts.

Activity: In this case we have designed a special exercise. Children look for the exercise in the Photos app and copy it in the Skitch app. Then they work with the main concepts learnt: browser, search tool, user and Internet. Once the exercise is finished, students will send it by mail.

Unit 8. Internet II: What do we search in the Internet? Information: the concept and sorts of information, i.e., textual, visual, multimedia. Who gives us the information? Different kinds of sources. What is a source? Why is it so important to know the source in order to appreciate the information?

Activity: This is a collective activity in which we all search the Internet and find some kind of information. We discuss it together trying to understand the source of the information and determining whether it is a good source or not.

\subsection{Third Step: Having results, making conclusions}

The final level of the project consists of three different parts: a) checking if the children have learnt something by reviewing the exercises they have done and shared in the classroom blog b) conducting the same interview as in the beginning of the project in order to see if children have learnt the main concepts and c) surveying the student's parents in order to determine how they feel about the project launched in their child's classroom.

a) The first part in this step will give us the keys to ensure the content of the units is suitable to the age and the understanding of the students.

b) We have conducted the same interview at the end of the sessions in order to check if there is any different knowledge the children have after the units about Internet.

\section{A CASE STUDY OF MEDIA LITERACY AT CLASSROOM: THE RESULTS}

The following section will present all the results obtained in the different steps of the project in order to track the evolution and development and ensure each step make sense.

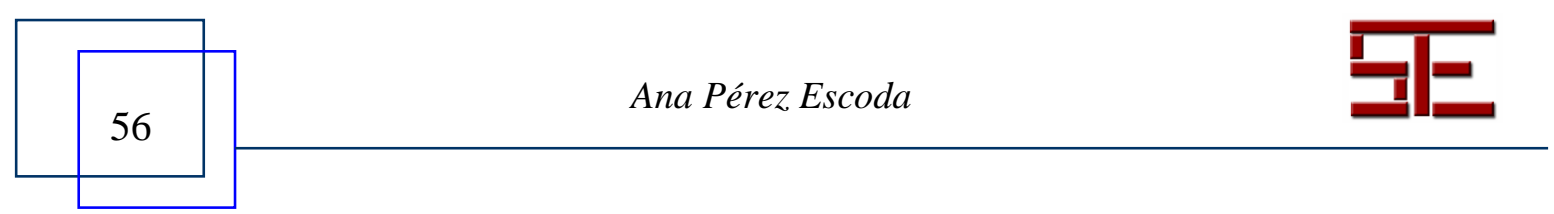




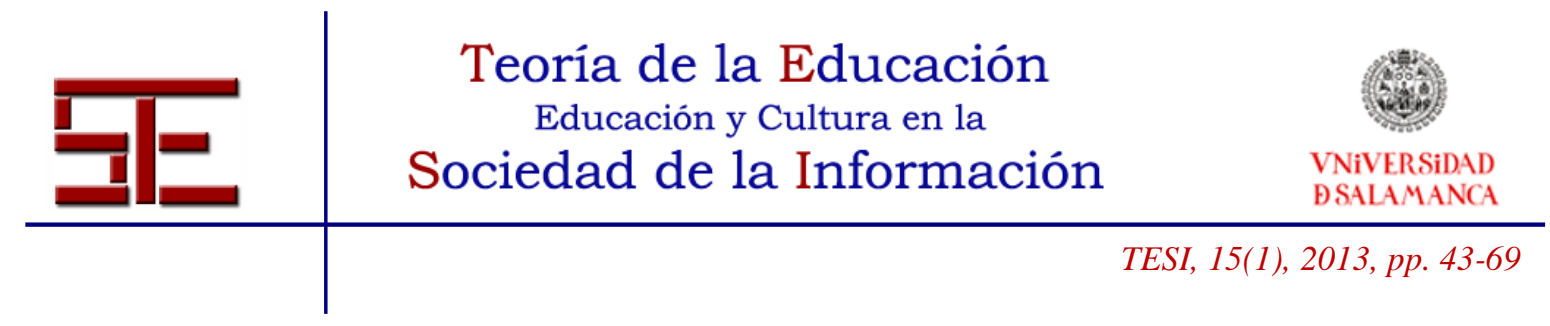

\subsection{First step: Motivation test and previous knowledge}

Motivation test: the results were interpreted according to the code given by Carmen Ávila de Encío ${ }^{4}$. Subsequently we obtained in table 3 the following results in the pretest for the sample in our study:

Table 3. Scoring from the motivation test

\begin{tabular}{|c|c|c|c|}
\hline SCORING & $\mathbf{N}^{\circ}$ OF STUDENTS & $\%$ & EVALUATION \\
\hline From 0 to 3 points & 1 & $3,8 \%$ & $\begin{array}{l}\text { The student is not motivated to } \\
\text { work at school }\end{array}$ \\
\hline From 4 to 6 points & 3 & $11,5 \%$ & $\begin{array}{l}\text { There is not motivation enough to } \\
\text { learn }\end{array}$ \\
\hline From 7 to 10 points & 22 & $84,6 \%$ & $\begin{array}{l}\text { The student is motivated and is } \\
\text { keen on learning }\end{array}$ \\
\hline
\end{tabular}

The results show that this is a group of highly motivated students, considering that the $84,6 \%$ of the children are very interested in working and facing the challenges at school. This is really positive for our project because it means students will accept and will be keen to face new challenges.

Interview: after reviewing all the interviews transcripts (26 interviews, one per student) we proceeded to categorize the data.

The transcribed data corresponds to the information gathered from the previous knowledge interviews applied in the classroom, which provided us with information regarding the level of knowledge about the Internet students had and how they use it. This step provides the information needed to develop new media resources.

Due to the nature of our research: qualitative and just descriptive with an ex-post facto design, we study the characteristic of the data we need to codify and categorize the data.

According to Miles and Huberman "content analysis is accomplished through the use of coding frames. The coding frames are used to organize the data and identify findings after open coding has been completed" (Miles and Huberman, 1994, 253). Thus codifying is the process of arranging things in a systematic order to make something part of a system or classification; to categorize.

Table 4 to 11 show the categories in our project, they are sorted from the interviews; these data will help to develop the new material for the classroom.

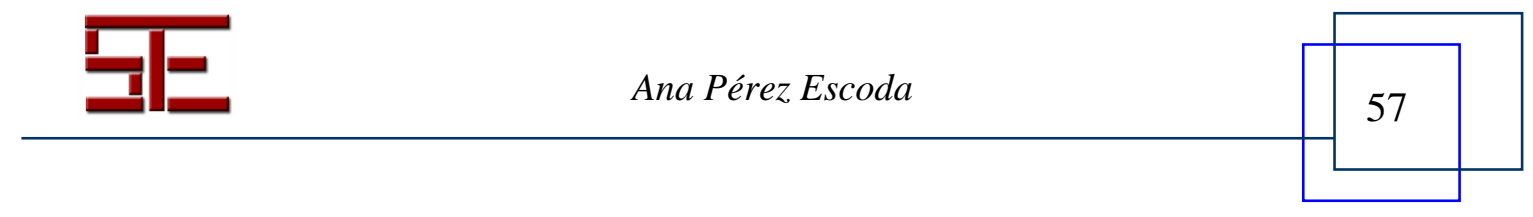




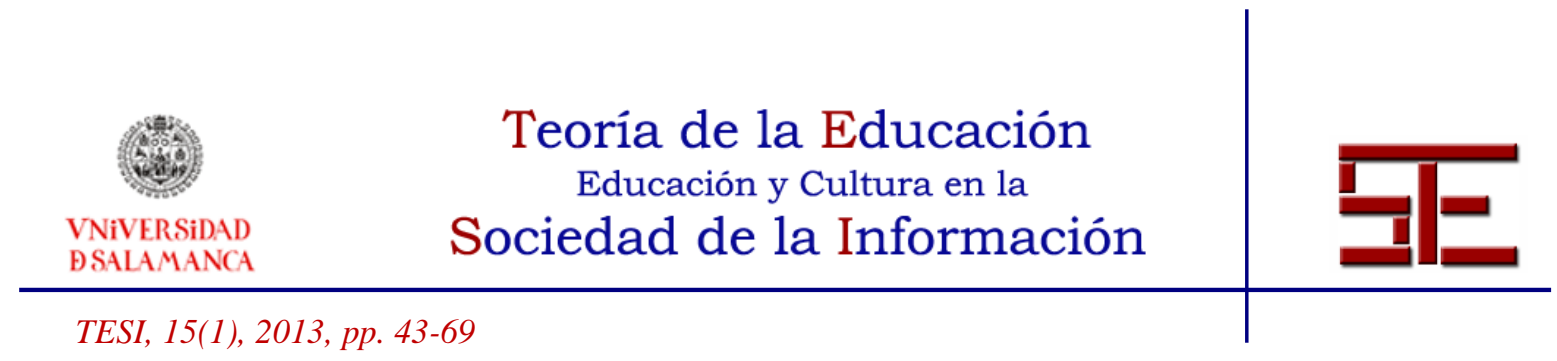

Table 4. Results from the first question

\begin{tabular}{|l|c|}
\hline QUESTION 1. WHAT IS THE INTERNET? & \\
\hline \multicolumn{1}{|c|}{ CATEGORIES } & No OF ANSWERS \\
\hline 1.I don't know & 5 \\
\hline 2.A computer program & 7 \\
\hline 3.The computer/Part of the computer & 3 \\
\hline 4.A web site & 5 \\
\hline 5.A network & 2 \\
\hline 6.Unknown & 4 \\
\hline
\end{tabular}

This first question shows that although they have all heard about the Internet they do not have a proper idea about what is it, just $7.6 \%$ able to identify the Internet as a network.

Table 5. Results from the second question

\begin{tabular}{|l|c|}
\hline QUESTION 2. WHAT IS IT FOR? & No OF ANSWERS \\
\hline \multicolumn{1}{|c|}{ CATEGORIES } & 4 \\
\hline 1.To play & 18 \\
\hline 2.To discover/know and learn & 2 \\
\hline 3.To work & 1 \\
\hline 4.To buy & 1 \\
\hline 5.To chat with friends and email them
\end{tabular}

Even though children do not exactly know what the Internet is, they know it is used for searching and learning new things: $65.3 \%$ knew this in our sample.

Table 6. Results from the forth question

\begin{tabular}{|l|c|}
\hline QUESTION 3. DO YOU SURF THE INTERNET? & No OF ANSWERS \\
\hline CATEGORIES & 24 \\
\hline 1.Yes & \\
\hline 2.No & \\
\hline
\end{tabular}

The results in this question demonstrate that children would need to begin thinking about this new area of Internet and its use at an early age because they are using it without any guidance: $92.3 \%$ say they already surf the Internet.

Table 7. Results from the fifth question

\begin{tabular}{|l|c|}
\hline QUESTION 3.1. WHAT DO YOU USE IT FOR? \\
\hline \multicolumn{1}{|c|}{ CATEGORIES } & No OF ANSWERS \\
\hline 1.For playing games & 12 \\
\hline 2.Finding things in Google & 12 \\
\hline
\end{tabular}

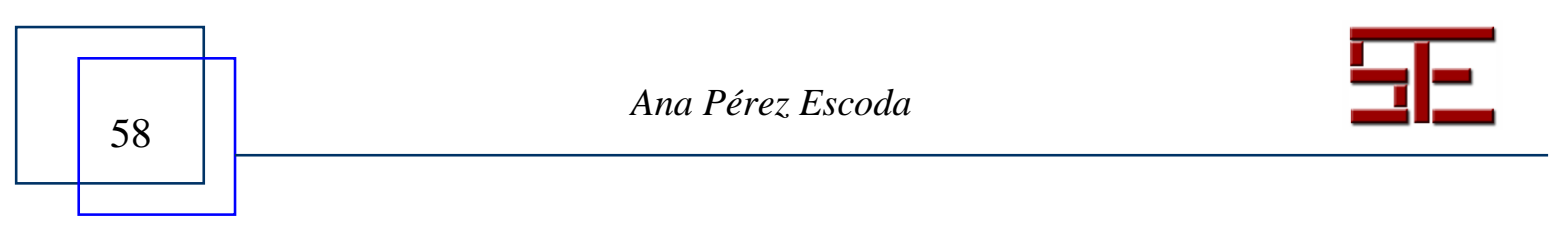




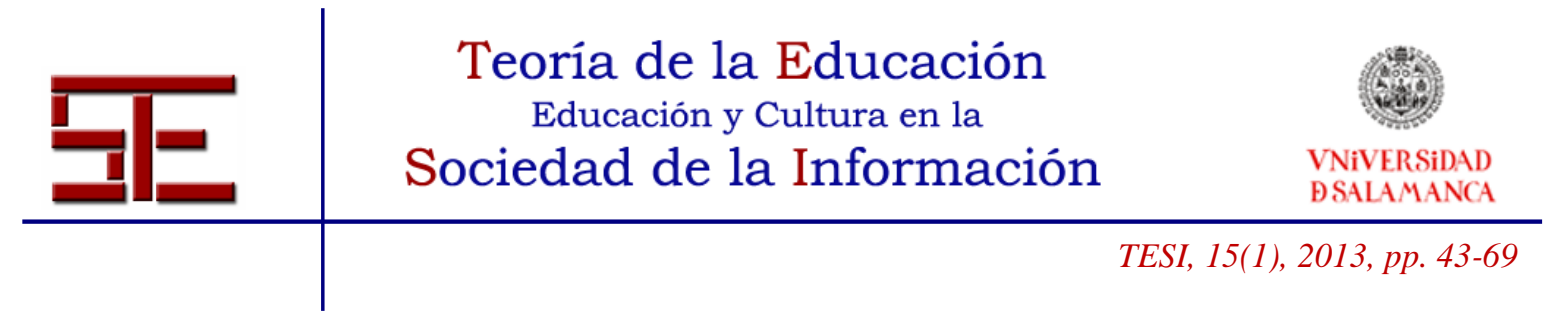

In this question we notice that $50 \%$ of the children use the Internet just to play, while the other half use the Internet to search for things.

Table 8. Results from the sixth question

\begin{tabular}{|l|c|}
\hline \multicolumn{1}{|c|}{ QUESTION 4. ARE YOU ALONE WHEN YOU SURF THE INTERNET? } \\
\hline \multicolumn{1}{|c|}{ CATEGORIES } & No OF ANSWERS \\
\hline 1.Sometimes alone sometimes with my parents & 12 \\
\hline 2.Yes, alone & 11 \\
\hline 3.With my parents & 2 \\
\hline
\end{tabular}

The answers in this question underscore the aims of our project: the urgent need of teaching children the skills they need to safely use the Internet. $42.3 \%$ of the children say they surf the Internet on their own, which means they are exposed to all the contents and all the risks that can be found in the Internet. Only $7.6 \%$ of the children say they surf with their parents.

Table 9. Results from the seventh question

\begin{tabular}{|l|c|}
\hline \multicolumn{1}{|c|}{ QUESTION 5. WHERE ARE YOU WHEN YOU SURF THE INTERNET? } \\
\hline 1.At home/in the dining room & N$^{\circ}$ OF ANSWERS \\
\hline 2.In my bedroom & 12 \\
\hline 3.In the study room & 2 \\
\hline 4.In my parent's room & 7 \\
\hline 5.In my grandparent's home & 2 \\
\hline
\end{tabular}

The fifth question provides us with the key to the problem: parents allow their children to surf the Internet, $92.3 \%$ surf the Internet at home (it is important to keep in mind that we are talking about 7 year old students). It is worth noting that $7.6 \%$ surf the Internet in their own bedrooms while alone and unsupervised.

Table 10. Results from the eighth question

\begin{tabular}{|l|c|}
\hline QUESTION 6. WHERE DO YOU USE IT? \\
\hline \multicolumn{1}{|c|}{ CATEGORIES } & No OF ANSWERS \\
\hline 1.Computer & 10 \\
\hline 2.Computer and mobile devices & 16 \\
\hline
\end{tabular}

This is a relevant question in our research about the use of different devices, not only computers, to surf the Internet. $61.5 \%$ of the students use different devices such as tablets, which confirms that children can manage the technology naturally.

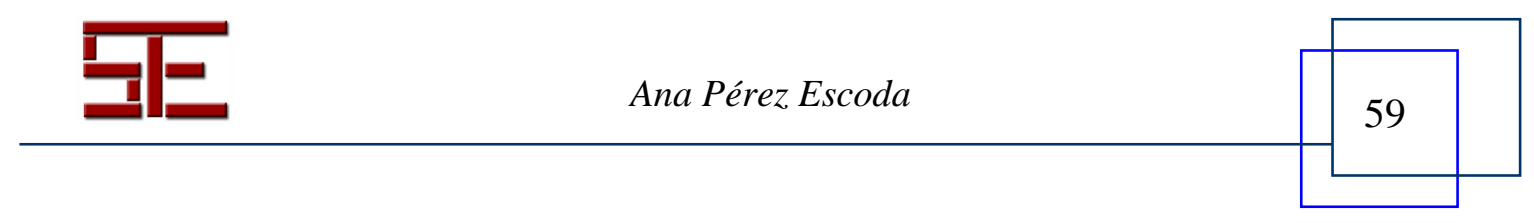




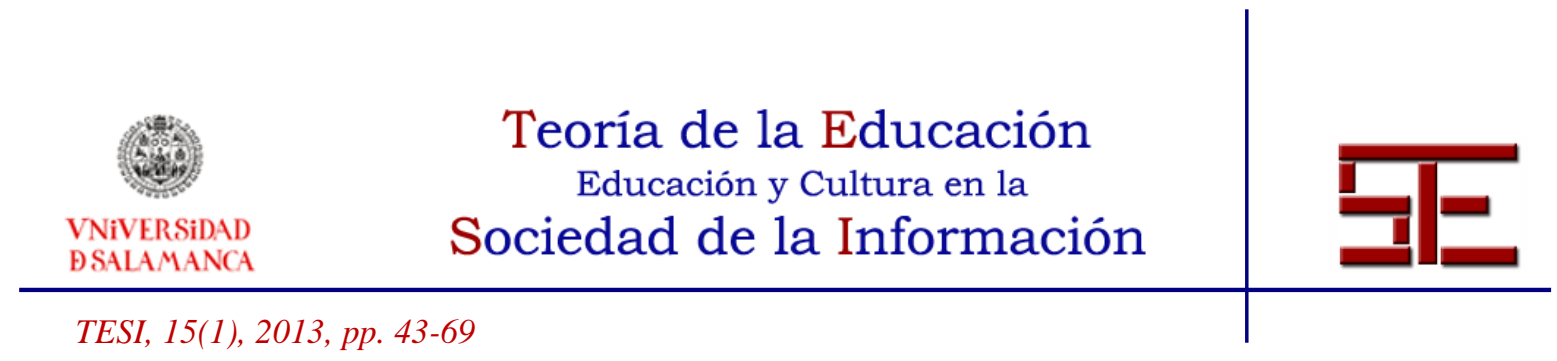

Table 11. Results from the forth question

\begin{tabular}{|l|c|}
\hline QUESTION 7. DOES IT HELP YOU LEARN? & No OF ANSWERS \\
\hline CATEGORIES & 7 \\
\hline 1. No & 19 \\
\hline
\end{tabular}

Finally, to conclude the questionnaire we find that $73 \%$ of children believe that the Internet could be used for learning, as opposed to $26.9 \%$ who say that the Internet does not help learning new contents.

All the data presented correspond to the first interview made at the beginning of the project. It is worth noting the differences between the first and second interview in which students have had lessons about media literacy. In tables 12 to 14 we can see how the questions alone can illustrate some differences in the knowledge the children have about the Internet before and after the learning units.

Table 12. Comparing results from the first and second interview

\begin{tabular}{|l|c|c|}
\hline \multicolumn{1}{|c|}{ QUESTION 1. WHAT IS INTERNET? } \\
\hline CATEGORIES & ANSWERS BEFORE & ANSWERS AFTER \\
\hline 1.I don't know & 5 & 1 \\
\hline 2.A computer program & 7 & 1 \\
\hline 3.The computer & 3 & 0 \\
\hline 4.A web site & 5 & 5 \\
\hline 5.A network & 2 & 9 \\
\hline 6.Unknown & 4 & 0 \\
\hline 7.A browser & & 3 \\
\hline 8.A search-engine & & 6 \\
\hline
\end{tabular}

The main evidence comparing data is the new perception students have about the concept of the Internet and the meaning it involves. As we can see no one in the second interview has answered "unknown" which means the lessons have been effective.

Table 13. Comparing results from the first and second interview

\begin{tabular}{|l|c|c|}
\hline \multicolumn{1}{|c|}{ QUESTION 2. WHAT IS IT FOR? } & & \\
\hline 1.To play & ANSWERS BEFORE & ANSWERS AFTER \\
\hline 2.To discover/know and learn & 4 & 4 \\
\hline 3.To work & 18 & 20 \\
\hline 4.To buy & 2 & 1 \\
\hline 5.To chat and email & 1 & 0 \\
\hline
\end{tabular}

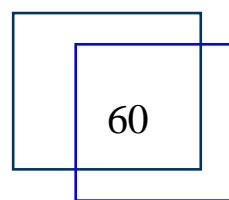

Ana Pérez Escoda

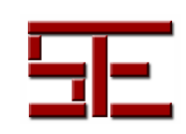




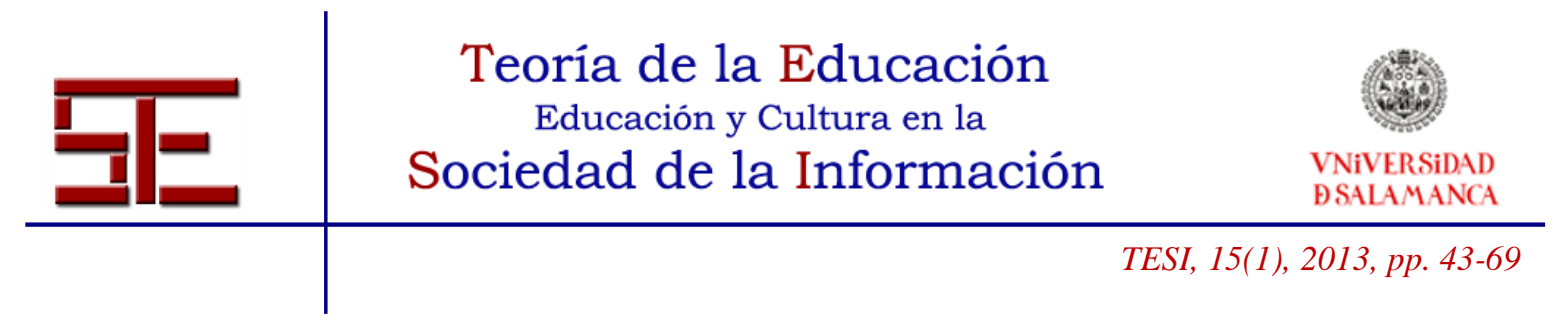

In this item the answers before and after the study are not truly different. It was quite interesting for us discover that children are using the Internet more in an educational way more than for pure entertainment, just for playing games.

Table 14. Comparing results from the first and second interview

\begin{tabular}{|l|c|c|}
\hline \multicolumn{2}{|c|}{ QUESTION 7. DOES IT HIELP YOU LEARN? } \\
\hline CATEGORIES & ANSWERS BEFORE & ANSWERS AFTER \\
\hline 1. No & 7 & 1 \\
\hline 2 .Yes & 19 & 26 \\
\hline
\end{tabular}

It was really interesting in this question to realize that the students changed their mind about the usefulness of the Internet after the learning unit. Children have discovered the educational use of the Internet that was a main aim in this project.

\subsection{Second step: Assessment of learning units}

Making sense of all the data previously explained, we shall now expose the results in all the activities students completed before every lesson in table 15 . The exercises were done using the iPads (individually or in pairs) and every activity was made with different apps specially chosen for the purpose of the activity.

Table 15. Percentage scale of the activities

\begin{tabular}{|c|c|c|c|c|c|}
\hline & Activity I & Activity II & Activity III & Activity IV & Activity V \\
\hline $\begin{array}{l}\text { Total success (students who } \\
\text { completed the activity) }\end{array}$ & $88 \%$ & $81 \%$ & $64 \%$ & $85 \%$ & $77 \%$ \\
\hline $\begin{array}{l}\text { Not quite right (students who did } \\
\text { not complete the activity) }\end{array}$ & $8 \%$ & $19 \%$ & $28 \%$ & $11 \%$ & $23 \%$ \\
\hline Students who did not participated & $4 \%$ & $4 \%$ & $8 \%$ & $4 \%$ & $0 \%$ \\
\hline
\end{tabular}

Fortunately the exercises the children sent to the classroom blog show that $90 \%$ of the children were able to achieve the objectives of the unit, as shown in the classroom blog (http://bit.ly/14Je7OH). This means the challenges the students faced are appropriate for them and they all feel capable of performing them. In Figure 3 is noted clearly the percentage of success in the activities done.

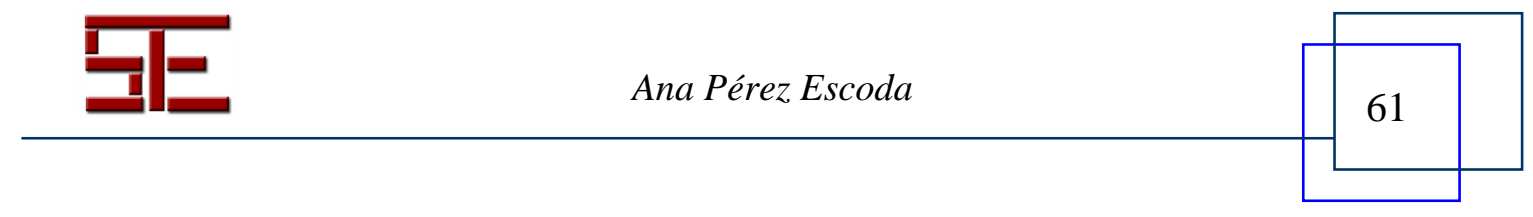



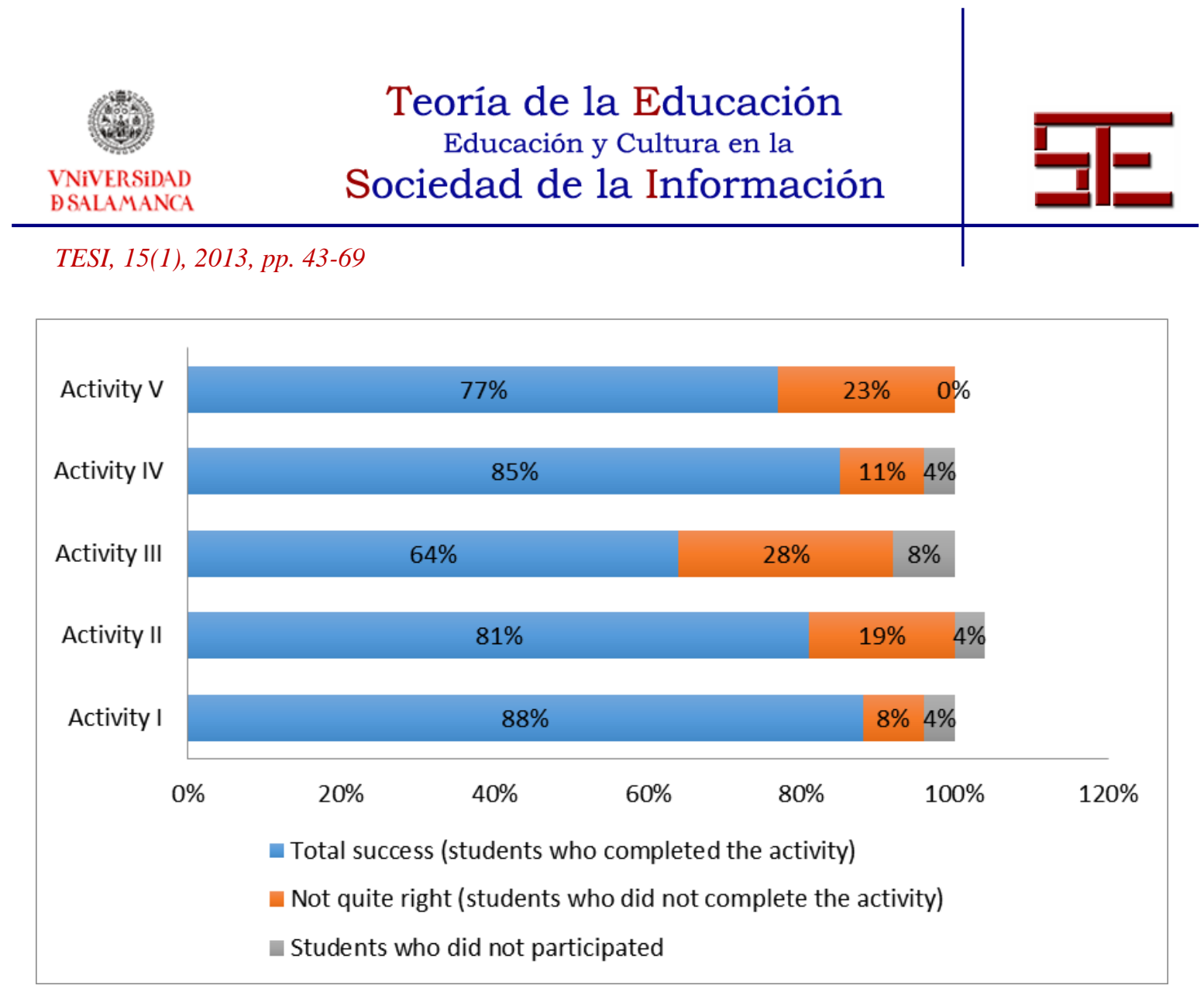

Figure 3. Success rate in the activities

\subsection{Third step: Parent's opinions and feelings about the project}

Finally, it must also be noted that parents are an important part in this type of project. We have previously analysed how technologies are revolutionizing all states of human life, we must now focus on family life. Usually children and parents alike need to build their digital skills: perhaps for this reason parents are somehow concerned about how their children use media and the Internet. This concern is rooted in the fact that sometimes children know more than parents about technologies (Plowman, Stephen and McPake, 2010).

Nevertheless parents are continuously buying new devices (smartphones, tablets, laptops) connected to the Internet and allowing their children unlimited use. For this reason we conducted a small survey in order to know the opinion of parents regarding this pilot project. We have identified the most relevant questions and answers below in Figures 4, 5 and 6:

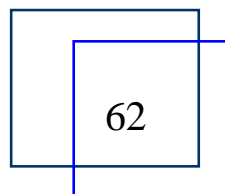

Ana Pérez Escoda 


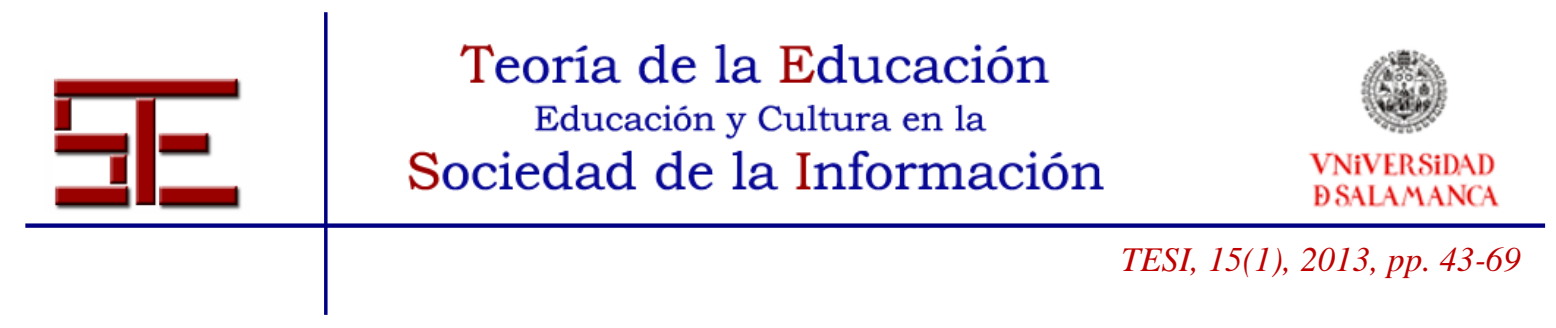

6. Does your son/daughter use the computer?

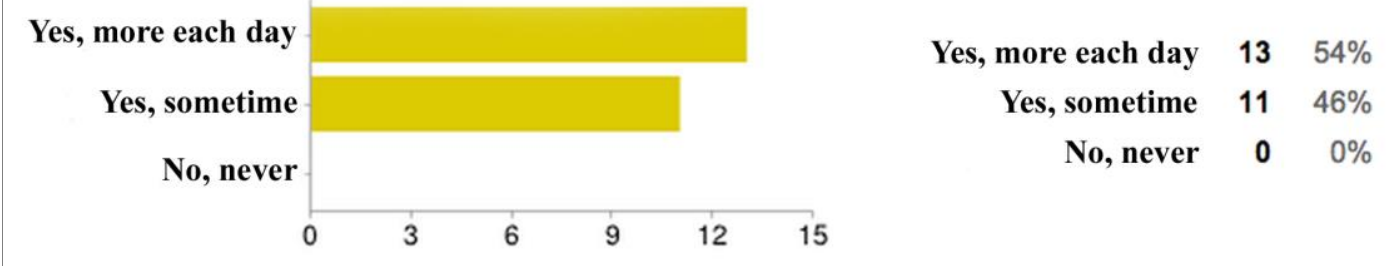

Figure 4. Some results from the Parent' Survey

In this case the question is made in order to check the use of the computer. Everybody use the computer and even $54 \%$ said "yes, more every time".

\section{Does your son/daughter use the Internet?}

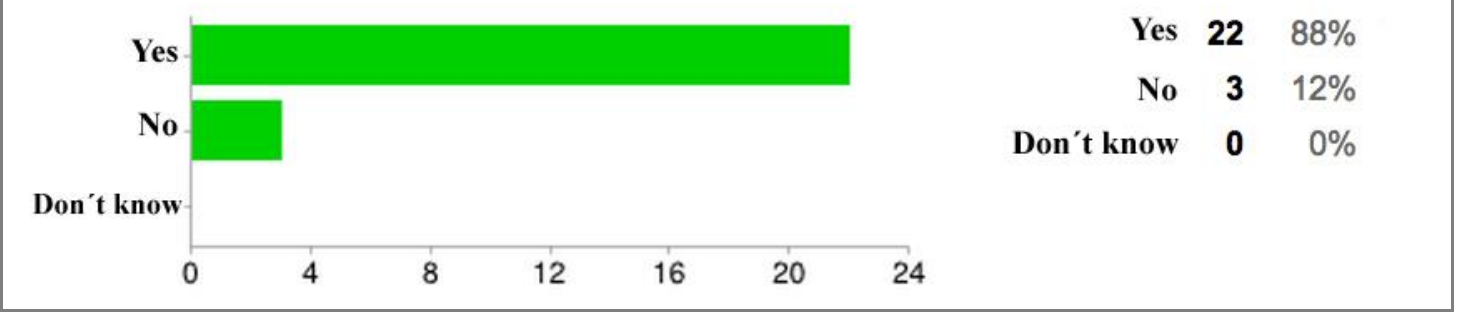

Figure 5. Some results from the Parent' Survey

This is a very significant question because it proves that children are using the Internet. $88 \%$ of the parents said "Yes" and only $12 \%$ said "No".

8. Do you think it is important for your children to learn about the Internet and its use?

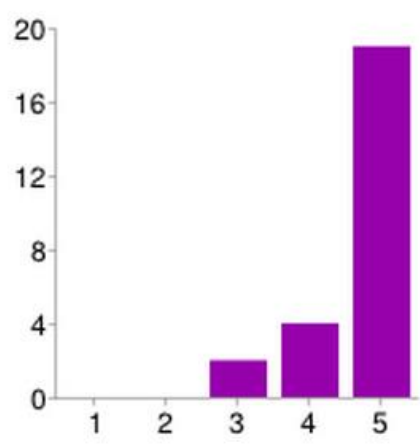

$\begin{array}{rrrr}\text { Not important } & 1 & \mathbf{0} & 0 \% \\ \text { Not very important } & \mathbf{2} & \mathbf{0} & 0 \% \\ \text { Somewhat important } & \mathbf{3} & \mathbf{2} & 8 \% \\ \text { Important } & 4 & \mathbf{4} & 16 \% \\ \text { Very important } & \mathbf{5} & \mathbf{1 9} & 76 \%\end{array}$

Figure 6. Some results from the Parent' Survey

$76 \%$ of the parents consider it very important to teach their children about the Internet and its use. This is a very good result for our proposal.

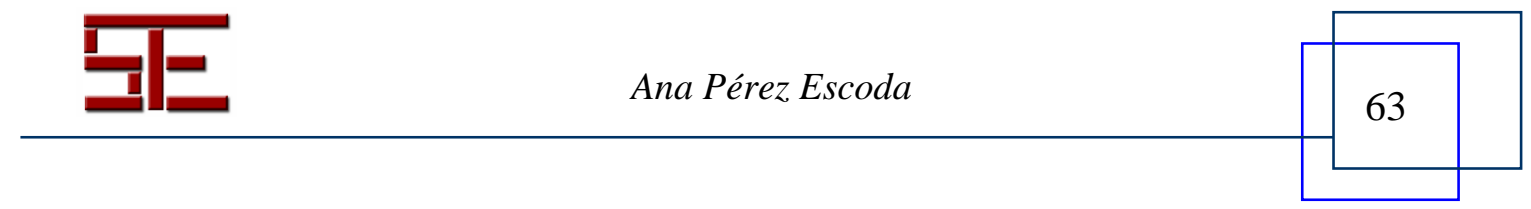




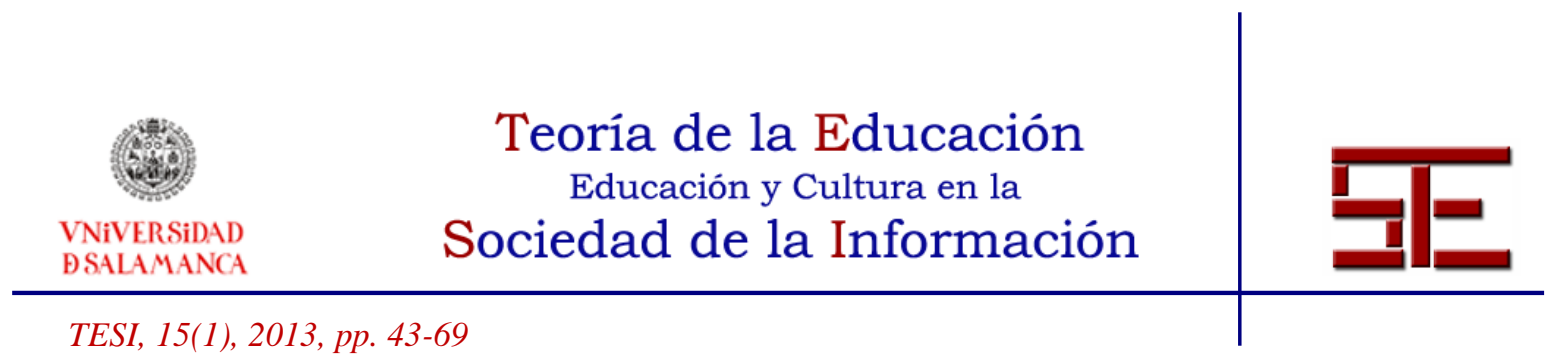

\section{CONCLUSIONS}

\subsection{Case study conclusions}

The evidence of the results obtained suggests the following points:

- Children are absolutely ready to manage new devices in the classroom in an educational way, and are absolutely predisposed to learn everything about the Internet, not only because they are "digital natives" but because they are already using the Internet (which they all declared in the interviews and their parents can confirm).

-Parents mostly agree with the idea that children must learn about the Internet and its use, and they mostly agree that these contents must be taught at school (as shown in the graphics). Given that household conditions about access to and use of the Internet and technologies have changed radically, the teaching of these competences could become a social demand.

-The teacher and the school that were involved in the project perceive how crucial and relevant those contents are, but they are not able to teach them without external help, which includes the development of new resources such as those created in this project. In summary, we can conclude that is necessary coordinate a collaborative effort between schools, teachers and researchers in order to reach the goals of the agreements on how new materials and resources are to be used.

-Bearing in mind the previous conclusions regarding the main "actors" involved (i.e., children, parents and schools), it must also be noted that even though the international community agree about the need for media literacy at schools, there are no formal contents developed in this respect. Therefore it is imperative for the academic field to contribute to this effort. As far as we are concerned, this project has clearly demonstrated this need and the results will encourage us to continue working longer in this direction. We strongly believe that it is worthwhile to be aware of the fact that change is the responsibility of all of us.

\subsection{General conclusions}

Finally, we could conclude some general considerations and advices:

-To conclude we might say that our world has acquired a speed of movement sometimes hard to follow, changes happen more quickly than ever in the past. This implies a big challenge to humanity because it supposes teaching new generations in very different ways from the ways of the past. Nevertheless if humans have achieved unthinkable progress in technology, we must be able to prepare future generations to face the digital age. The world has become smaller because communication has become faster (Westera, 2013); the people in the 20th

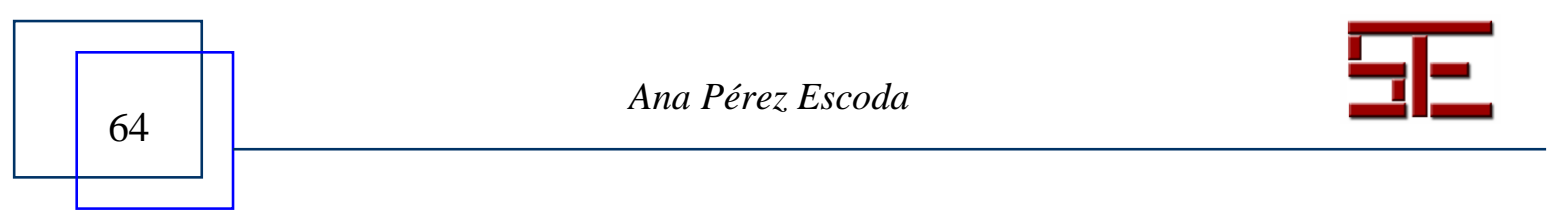




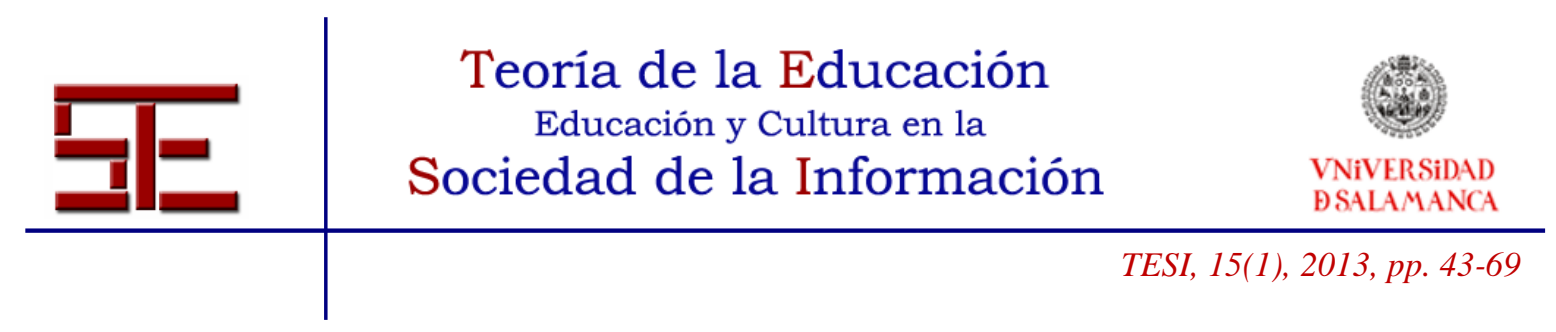

Century were trained to talk and relate with small groups, while in the 21 st Century people need to be prepared to connect with the world.

-On other hand we will briefly underscore that if policy helps people that were born in an analogue world to learn digital skills and new abilities, and also grants young people the ability to develop digital competences ${ }^{5}$ it means we are somehow managing to deal with the situation. However this is not enough. Because of equal importance is the need to bear in mind that new generations are the young children who urgently need an education adapted to their times. New settings must be established in primary school when children begin surfing the Internet and experiencing minor problems that will eventually lead to bigger problems (e.g. grooming, sexting, cyberbullying) if they are not properly educated.

-Another relevant question to conclude with are the benefits that are obtained when we focus on the possibilities and wisdom that children could have with media literacy. According to the words of the authors Jose Manuel Pérez Tornero and Tapio Varis $(2010,44)$ the main values of media literacy are: a) the defence of individual autonomy based on critical thinking; b) the constructive value of open, participatory dialogue; c) personal and collective creativity and the imagination; d) the upholding of an active, communicative democracy and e) the value of understanding and respecting for cultural diversity and dialogue among cultures.

-Finally we will go one step further. If it is important to develop new materials about media literacy such as information, communication, content creation, safety, it would also be necessary to implement new subjects at the university level where the new candidates in education have the hope of achieving a proper training to become good teachers. It is evident that the sooner we begin training teachers to teach in the digital age the better their chances of teaching children the new competences.

\section{ACKNOWLEDGMENTS}

The pilot-project exposed in this essay obtained a special award from the University of Salamanca: "Premio de Educación Perfecta Corselas" XII Edition (January 2013December 2013).

\section{REFERENCES}

Aguaded-Gómez, I. (2011). Niños y adolescentes: nuevas generaciones interactivas. Comunicar, 36, 7-8.

Alonso Tapia, J. (2005). Motivación para el aprendizaje: la perspectiva de los alumnos. La Orientación Escolar en Centros Educativos, 209-242. Madrid: MEC.

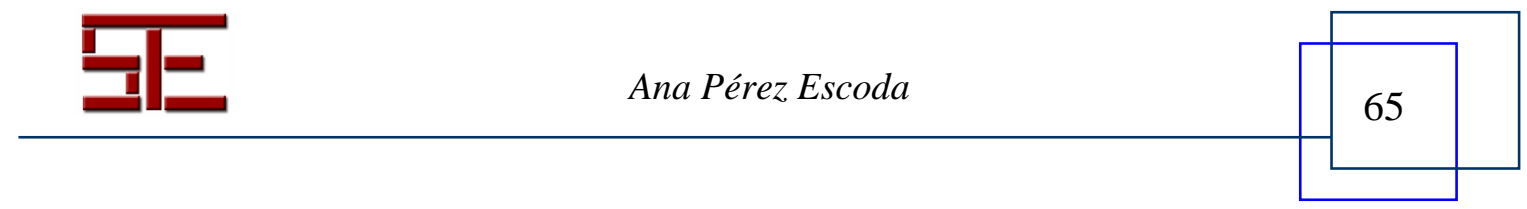




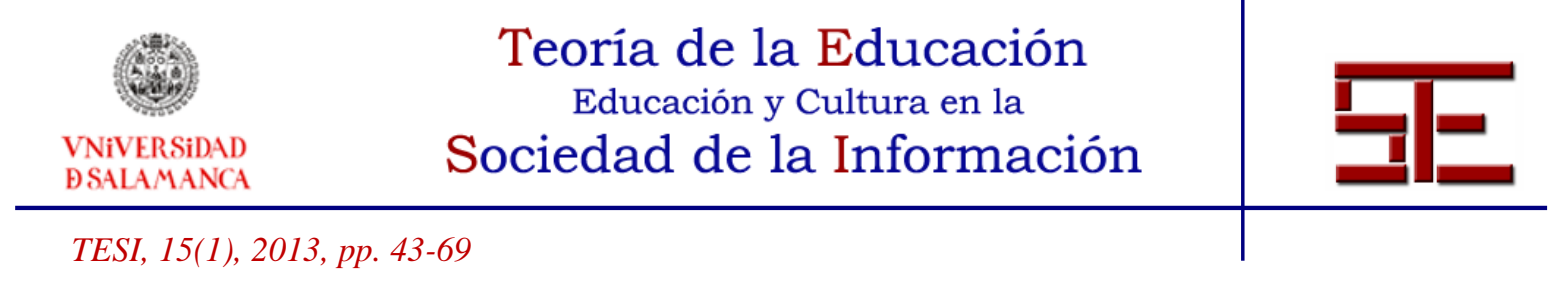

Andretta, S. (2007). Phenomenography: a conceptual framework for information literacy education. Aslib Proceedings, 59 (2), 152-168.

Area, M. and Guarro, A. (2012). La alfabetización informacional y digital: fiundamentos pedagógicos para la enseñanza y el aprendizaje competente. Revista Española de Documentación Científica, 35, 46-74.

Bauman, Z. (2007). Los retos de la educación en la modernidad líquida. Barcelona: Gedisa.

Bautista García-Vera, A. (2007). Alfabetización tecnológica multimodal e intercultural. Revista de Educación, 343, 589-600.

Bringué, X. and Sábada, C. (2010). Niños y adolescentes españoles ante las pantallas: rasgos configuradores de una generación interactiva. [Versión electrónica]. CEE Participación Educativa, 15, 86-104.

Bruce, C. (1997). The seven faces of information literacy. Adelaide: Auslib Press.

Burn, A. and Durran, J. (2007). Media Literacy in Schools: Practise, productions and progression. London: SAGE.

Castells, M. \& Cardoso, G. (2005). The network society. From Knowledge to Policy. Washington, DC: Johns Hopkins Center for Transatlantic Relations.

Catts, R. \& Lau, J. (2009). Hacia unos Indicadores de Alfabetización Informacional. Madrid: Ministerio de Cultura.

Churchill, D., Churchill, N., Lim Cher Ping \& Oakley, G. (2008). Digital storytelling and digital literacy learning. Proceedings of International Conference on Information Communication Technologies in Education (ICICTE), 418-430.

Churchill, D. (2009). Literacy in the web 2.0 world (New Literacy). Retrieved October 20, 2013, from http://www.slideshare.net/zvezdan/new-literacy-in-the-web-20world.

Churches, A. (2009). Bloom's digital Taxonomy. Retrieved from http://edorigami.wikispaces.com/file/view/bloom's+Digital+taxonomy+v3.01.pdf

Cohen, D. (2009). Three lectures on post-industrial society. Cambridge: MIT Press.

Collins, A. \& Halverson, R. (2009). Rethinking education in the age of technology: the digital revolution and schooling in America. NY: Teachers College Press.

Cope, B., \& Kalantzis, M. (2009). Multiliteracies: New Literacies, New Learning. Pedagogies: An International Journal, 4 (3).

Deursen, A. \& Van Dijk, J. (2010). Measuring Internet Skills. International Journal of Human-Computer Interaction, 26, 891-916.

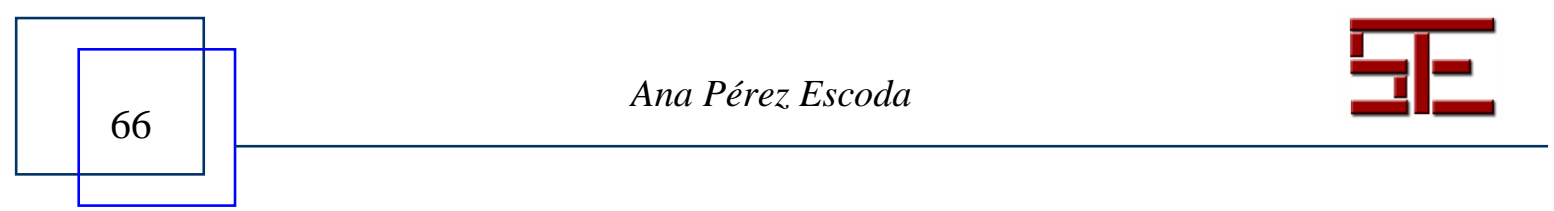




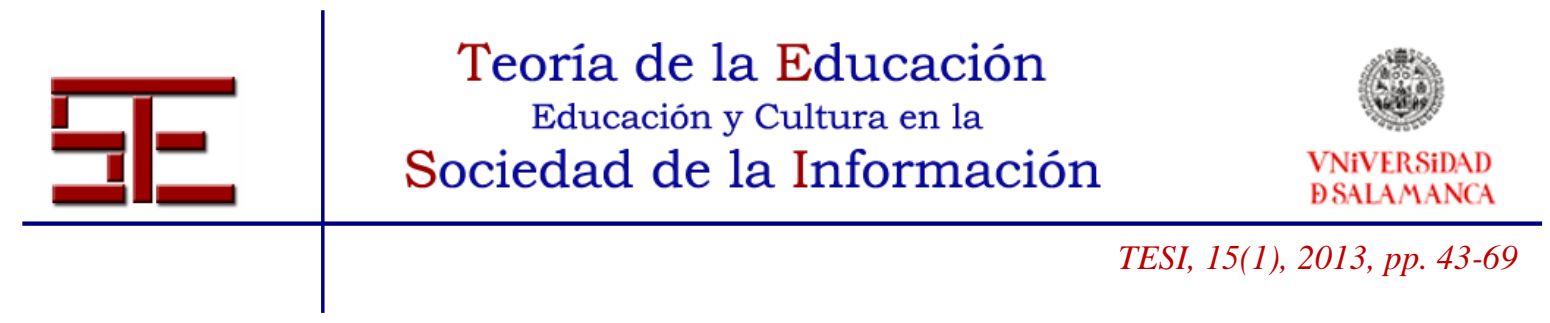

Diehm, R.A. \& Lupton, M. (2012). Approaches to Learning Information Literacy: A Phenomenographic Study. Journal of Academic Librarianship, 38 (4), 217-225.

Ferrari, A. (2013). DIGCOMP: A framework for developing and understanding digital competence in Europe. Sevilla: European Commission.

Jenkins, H. (2008). Convergence culture. Where the old and new media collide. New York: New York University.

Jewitt, C. (2002). Raising standards in literacy. En R. Fisher, M. Lewis, G. Brooks, (Eds.), Globalisation, literacy curriculum practice (pp. 231-250). London: Routledge,

Kress, G. (2006). Literacy in the new media age. London: Routledge.

Lankshear, C. (2008). Nuevos alfabetismos su práctica cotidiana y el aprendizaje en el aula. Madrid: Morata.

Miles, M. B. \& Huberman, A. M. (1994). Qualitative data analysis. California: SAGE.

Negroponte, N. (1995). Being digital. New York: Vintage Publishing.

New London Group (1995). A pedagogy of multiliteracies: designing social futures. Haymarket: NLLIA Centre for Workplace Communication and Culture.

Ortega, J. F. \& Rodríguez, J. (2011). El Potlatch digital. Wikipedia y el triunfo del precomún y el conocimiento compartido. Madrid: Cátedra.

Pahl, K. and Rowsell, J. (2012). Literacy and Education. Understanding the new literacy studies in the classroom. Second Edition. London: SAGE.

Pérez-Tornero, J. and Varis, T. (2010). Media Literacy and New Humanism. Moscow: UNESCO. Institute for Information Technologies in Education.

Plowman, L., Stephen, C. and McPake, J. (2010). Growing up with technology. Young children learning in a digital age. New York: Routledge.

Prensky, M. (2011). Teaching digital natives. EU: Corwin Press Inc.

UNESCO (2005). Hacia las sociedades del conocimiento. París: UNESCO.

-(2011). Media and Information Literacy Curriculum for Teachers. Paris:

Retrieved

from

http://unesdoc.unesco.org/images/0019/001929/192971e.pdf.

Van Dijk, J. and Hacker, K. (2003). The Digital Divide as a Complex and Dynamic Phenomenon. The information Society, 19, 315-326.

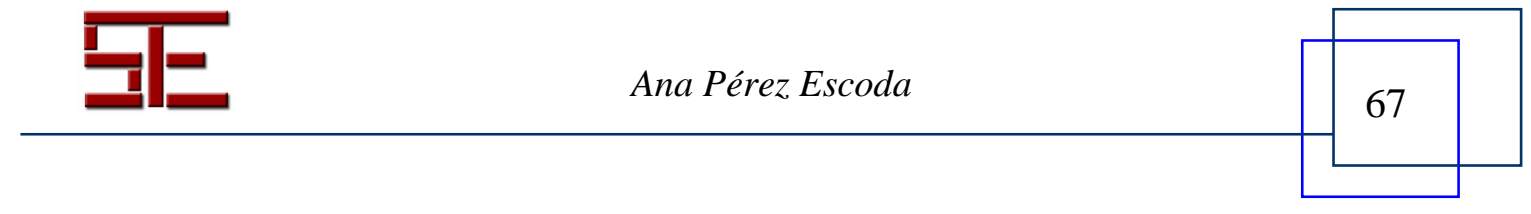




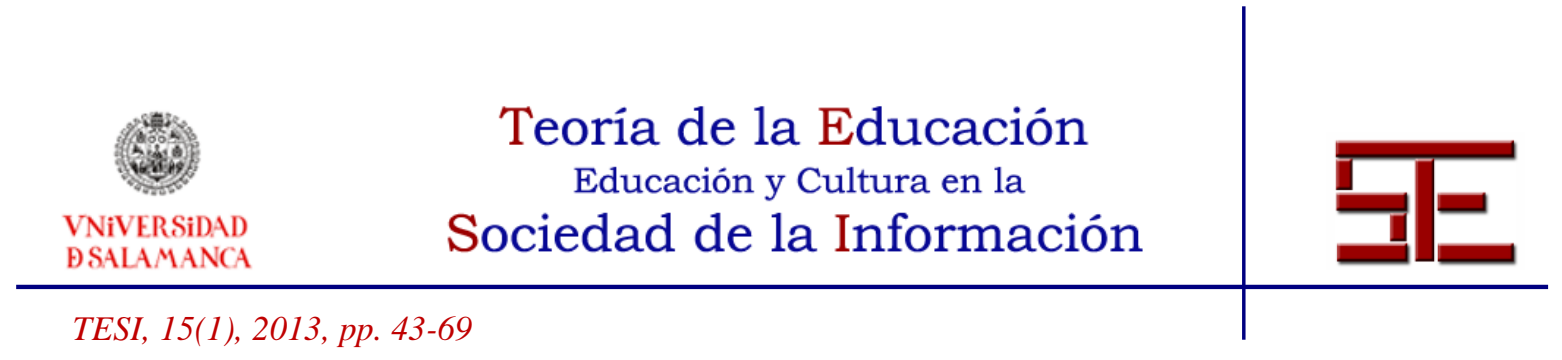

Van Dijk, J. (2012). The evolution of the Digital Divide. En J. Bus, M. Crompton, M. Hildebrandt, G. Metakides. (Eds.), Digital Enlightenment Yearbook 2012, 57-75. Amsterdam: IOS Press BV.

Weiner, S. A. (2010). Information Literacy: A neglected core competency. Educase Quarterly, 33 (1). Retrieved from http://www.educause.edu/EDUCAUSE+Quarterly/EDUCAUSEQuarterlyMagazine Volum/InformationLiteracyANeglectedC/199382.

Westera, W. (2013). The digital turn. How the Internet transforms our existence. Indiana: AuthorHouse.

Wolton, D. (2000). Surviving the Internet. Barcelona: Gedisa.

\section{NOTAS}

1 Before talking about media literacy in a deeper sense it should be necessary to make a definition of the concept. In this case it has been chosen a Pérez Tornero's definition, member of the European Commission in charge of the development of media literacy: "Media literacy can be defined as the capacity to access, analyse and evaluate the power of the images, sounds and messages with which we are faced every day and which play an important role in contemporary culture. It includes the individual capacity to communicate using the media competently. Media literacy concerns all media, including television, film, radio and recorded music, the press, the Internet and any other digital communication technology. The purpose of media literacy is to raise the level of awareness of the different guises taken on by the messages transmitted by the media that we find in our lives every day. This must help citizens to recognise how media filter their perceptions and convictions, mould popular culture and influence personal decisions. It should provide citizens with the capacity for critical analysis as well as creative problem-solving capacities, turning them into aware, productive consumers of information themselves. Media education is part of the fundamental rights of each citizen in every country in the world, just like the freedom of expression and the right to information, and it is crucial to the attainment and consolidation of democracy. Today, media literacy is one of the key prerequisites for the exercise of full, active citizenship, and it is one of the spheres inside which intercultural dialogue should be promoted" (Pérez Tornero and Varis, 2010, 73).

2 Due all these new concepts it might be useful define some of them according to the authors Pahl and Rowsell (2012) glossary terms XIX:

Multiliteracies: Using different linguistic systems within the same space. For example, homeschool book-making using different languages and dual texts.

Multimodal literacy: literacy teaching and learning that takes account of all modes within texts of all kinds.

Multiple literacies: different linguistic systems working within the same space. For example, Chinese, Turkish and English students working on a language activity at a writing centre.

3 The European Recommendation on Key Competences is an annex of a recommendation of the European Parliament and of the Council of 18 December 2006 on key competences for lifelong learning that was published in the Official Journal of the European Union on 30 December/L394 (http://ec.europa.eu/dgs/education_culture/publ/pdf/ll-learning/keycomp_en.pdf).

4 In the final recount it is a point for every response coinciding with the following code in which the number is fitting with every question number in the questionnaire and "T" means true and " $F$ " means false: $1 \mathrm{~T}, 2 \mathrm{~F}, 3 \mathrm{~F}, 4 \mathrm{~T}, 5 \mathrm{~F}, 6 \mathrm{~F}, 7 \mathrm{~T}, 8 \mathrm{~F}, 9 \mathrm{~T}$ and $10 \mathrm{~T}$. So, according to the punctuation obtained we would

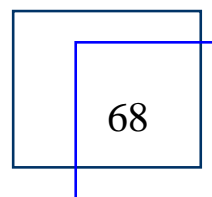

Ana Pérez Escoda

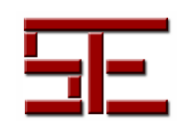




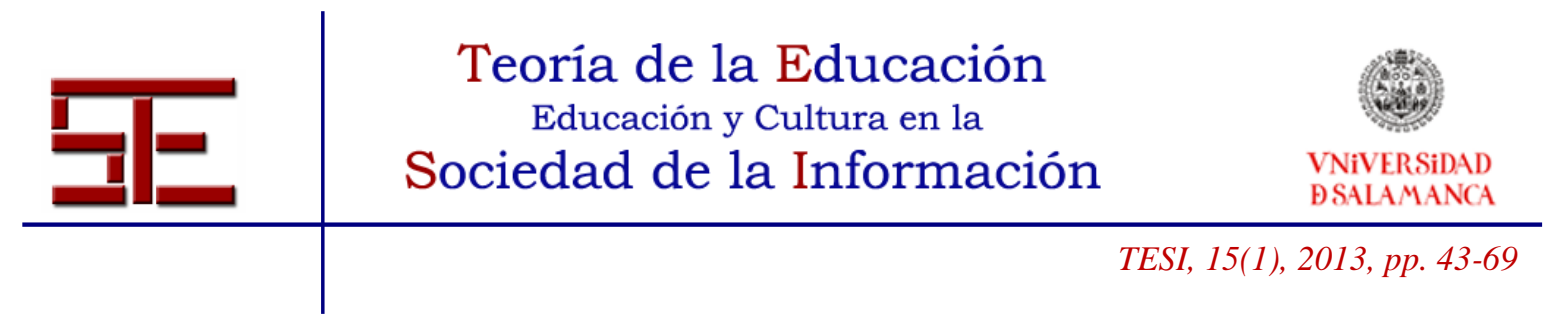

have: from 0 to 3 points: the child is not motivated; from 4 to 6 points: the child does not have sufficient motivation and from 7 to 10 points: the child is really motivated and is keen to face the work at school.

5 The Europeans Commission's Lifelong Training Programme enables people at all stages of their lives to take part in simulating learning experiences, as well as helping to develop the education and training sector across Europe (http://ec.europa.eu/education/lifelong-learningprogramme/doc78_en.htm).

Para citar el presente artículo puede utilizar la siguiente referencia:

Pérez Escoda, A. (2014). Media literacy in primary school: new challenges in the digital age. Revista Teoría de la Educación: Educación y Cultura en la Sociedad de la Información. 15(1), 43-69 [Fecha de consulta: dd/mm/aaaa].

http://campus.usal.es/ revistas_trabajo/index.php/revistatesi/article/view/11652/12067

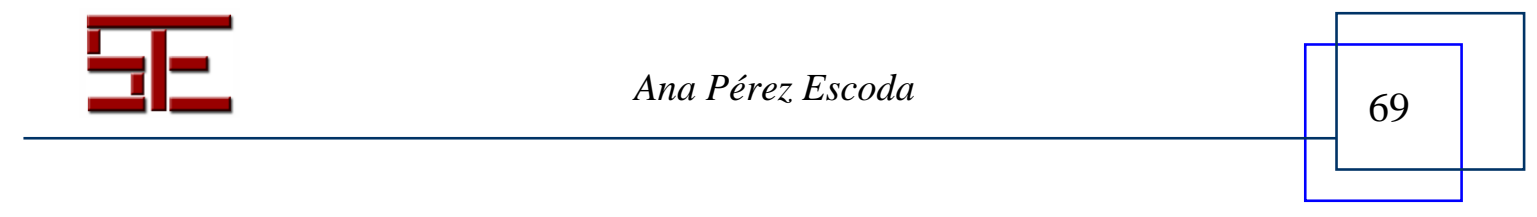

